\title{
Aptian sedimentation in the Recôncavo-Tucano-Jatobá Rift System and its tectonic and paleogeographic significance
}

\author{
Bernardo T. Freitas ${ }^{\text {a, b, * }}$, Renato P. Almeida ${ }^{\text {b }}$, Simone C. Carrera ${ }^{\text {b, c }}$, Felipe T. Figueiredo ${ }^{\text {b, c }}$, \\ Bruno B. Turra b, d, Filipe G. Varejão ${ }^{e}$, Mario L. Assine ${ }^{\mathrm{e}}$ \\ a Faculdade de Tecnologia, Universidade Estadual de Campinas, Rua Paschoal Marmo, 1888, Jd. Nova Itália, Limeira, SP, CEP 13484-332, Brasil \\ ' ${ }^{\mathrm{b}}$ Instituto de Geociências, Universidade de São Paulo, Rua do Lago, 562, Cidade Universitária, São Paulo, SP, CEP 05508-900, Brasil \\ ${ }^{\mathrm{c}}$ Departamento de Geologia, Universidade Federal de Sergipe, Av. Marechal Rondom, S/N, Rosa Elze, São Cristóvão, SE, CEP 49100-000, Brasil \\ ' CPRM - Serviço Geológico do Brasil, Rua Costa, 55, Cerqueira César, São Paulo, SP, CEP 01304-010, Brasil \\ e Instituto de Geociências e Ciências Exatas, Universidade Estadual Paulista, Avenida 24 A, 1515, Rio Claro, SP, CEP 13506-900, Brasil
}

\section{A R T I C L E I N F O}

\section{Article history:}

Received 28 February 2017

Received in revised form

17 September 2017

Accepted 3 October 2017

Available online 5 October 2017

\section{Keywords:}

Gondwana paleogeography

Big rivers

Controls on sedimentation

Marizal formation

Banzaê member

Cícero dantas member

\begin{abstract}
A B S T R A C T
This study, based on detailed sedimentologic and stratigraphic analysis of the Aptian succession preserved in the Recôncavo-Tucano-Jatobá Rift System (RTJ), present new elements for biostratigraphic correlation and paleogeographic reconstruction in the mid-Cretaceous South Atlantic realm, supporting novel interpretations on the tectonic and sedimentary evolution related to the W-Gondwana breakup. The Aptian sedimentary succession in the RTJ has been referred to as Marizal Formation, and interpreted as post-rift deposits. Detailed sedimentologic and stratigraphic studies of these deposits enabled the recognition and individualization of two distinctive sedimentary units that can be traced in the entire RTJ. These units are here described and named Banzaê and Cícero Dantas members of the Marizal Formation. Their contact is locally marked by the fossiliferous successions of the here proposed Amargosa Bed, lying at the top of the Banzaê Member. Both members of the Marizal Formation record large river systems captured by the Tucano Basin with the local development of eolian dune fields and faultbounded alluvial fans. The Amargosa Bed represents a regional-scale base level change preserved between the Aptian fluvial successions along the RTJ. Hence, the studied sedimentary record presents important implications for the timing and direction of marine ingressions affecting NE-Brazil interior basins during the Aptian. A remarkable contrast in preserved fluvial architecture between the Banzaê Member, characterized by connected channel bodies, and the Cícero Dantas Member, characterized by isolated channel bodies within overbank fines, is here reported. The main interpreted control for the observed contrast in fluvial stratigraphy is sedimentary yield variation. The interval is also subject to the interpretation of a regional shift in the mechanism responsible for the subsidence of the basins formed during the Cretaceous break-up of the Central South Atlantic. This view is challenged by our results which reveal that basin forming extension continued throughout the Aptian. As a conclusion, the detailed stratigraphy of the Marizal Formation forward alternative geodynamic interpretations for the Aptian successions in northeastern Brazil, bringing new elements to the mid-Cretaceous biogeographical, paleogeographical and tectonic reconstructions of western Gondwana.
\end{abstract}

() 2017 Elsevier Ltd. All rights reserved.

\footnotetext{
* Corresponding author. Faculdade de Tecnologia, Universidade Estadual de Campinas, Rua Paschoal Marmo, 1888, Jd. Nova Itália, Limeira, SP, CEP 13484-332, Brasil.

E-mail addresses: bernardotf@gmail.com, bernardotf@ft.unicamp.br (B.T. Freitas).
}

\section{Introduction}

The study here presented addresses central questions to the Cretaceous tectono-sedimentary evolution of the South Atlantic, with fundamental implications for Brazilian and African Petroleum Geology. Through the detailed sedimentologic and stratigraphic study of the Aptian succession preserved in the Recôncavo-TucanoJatobá Rift System (RTJ), key geodynamic, biostratigraphic and 
paleogeographic aspects of the W-Gondwana breakup during the Cretaceous are appraised.

The Aptian units in the RTJ are the youngest, widely distributed and better exposed Cretaceous sedimentary deposits preserved in this rift system. They are interpreted as being coeval with massive evaporite successions to the south (in the Campos and Santos Basins), deposited during an important interval in the evolution of the Central South Atlantic, close in time to seafloor spreading initiation (e.g. Milani et al., 2007; Chaboureau et al., 2013). Nonetheless, their sedimentological, stratigraphical, and structural characteristics are poorly described, partly because they are not part of the petroleum systems of the Cretaceous interior basins of northeastern Brazil.

The Aptian succession in the RTJ is ascribed to the Marizal Formation and to the Santana and Araripe groups (Neumann and Rocha, 2013), being usually interpreted as the sedimentary response to the onset of thermal subsidence following Berriasian to Barremian syn-rift mechanical subsidence (e.g. Magnavita et al., 1994; Milani et al., 2007). Nevertheless, direct application of classical models of uniform lithospheric extension (McKenzie, 1978; Wernicke, 1985) has been challenged by the recognition and numerical modeling, of a syn-rift sag phase produced by mechanical subsidence due to ductile thinning of middle and lower crust in offshore basins of the Central South Atlantic in Brazil and Africa, (e.g. Karner and Driscoll, 1999; Marton et al., 2000; Karner et al., 2003; Huismans and Beaumont, 2008, 2011; Aslanian et al., 2009; Unternehr et al., 2010).

In this context, Chaboureau et al. (2013) accounted the unconformity that was previously interpreted as the break-up (or postrift) unconformity (e.g. Bueno, 2004; Milani et al., 2007) as the base of syn-rift sags developed during the Aptian in the RTJ and elsewhere in the Central South Atlantic rift system. Alternatives to the thermal post-rift scenario have also been suggested by outcrop studies in the RTJ, in which the occurrence of Aptian conglomerate and breccia-dominated deposits sourced from the nearby basement were interpreted as alluvial fan deposits developed along active, fault-bounded, basin borders (e.g. Magnavita et al., 2000; Figueiredo et al., 2016).

To contribute to the discussion above, a detailed stratigraphic description of the Aptian succession in the RTJ is presented, with special regard to the Marizal Formation in the Tucano Basin and the here proposed subdivisions, namely the Banzaê and Cícero Dantas members and the Amargosa Bed. These units are interpreted in terms of their sedimentological characteristics, spatial distribution and relationships with the structural framework of the basin in order to interpret autogenic and allogenic controls on the Aptian sedimentation of the RTJ. Additionally, the here presented detailed description of the Marizal Formation should be useful in regional correlation and in mid-Cretaceous paleogeographical and geodynamic reconstructions of the Central South Atlantic in the context of the W-Gondwana breakup.

\section{Methods}

The Aptian sedimentary succession of the Tucano Basin was tackled through geological mapping, with measurement of detailed stratigraphic sections and acquisition of high resolution, laterally continuous, photo mosaics supporting facies and architectural element analysis (e.g. Reading, 1986, 1996; Walker, 1992; Miall, 1985, 1996; Bridge, 1993, 2003; Bristow, 1996). A new geological simplified map emphasizing the distribution of Aptian rocks in the RTJ (Figs. 1 and 2) was elaborated based on new data from the Tucano Basin, complemented with interpretation of SRTM (Shuttle Radar Topography Mission) digital elevation models (Fig. 1) and integration with previous maps (e.g. Lima and Vilas Boas, 2000; Souza et al., 2003; Magnavita et al., 2005; Dantas and Filho,
2006; Santos et al., 2010; Santos and Reis, 2011).

Fieldwork focused on the Tucano Basin, with higher density of outcrop descriptions in the Central Tucano Sub-basin and the Vaza Barris River Valley (Fig. 1). Although outcrop descriptions were made in all the basins of the RTJ, information on the Jatobá Basin was mainly derived from the synthesis of Dantas and Filho (2006), whereas data on the Recôncavo Basin were compiled from the previous works of Lima and Vilas Boas $(1994,2000)$ and Magnavita et al. (2005). The geology of the latter basins was then reinterpreted based on geomorphological criteria established in the Tucano Basin (see below).

The results here presented are a synthesis of geological mapping, sedimentological and stratigraphic studies, carried out in the Tucano Basin. Each point presented in the point map (Fig. 1) represents the detailed description of at least one stratigraphic panel a few meters high and with tens of meters in width. Several points refer to described mosaics tens of meters high and hundreds of meters long, especially in the Central Tucano Sub-basin. The database underpinning this study is thus composed of hundreds of architectural panels, and related stratigraphic logs, oriented in every possible direction regarding interpreted paleoflows. Part of this field database was published in recent methodological contributions (e.g. Figueiredo et al., 2016; Tamura et al., 2016; Almeida et al., 2016a, 2016b). A detailed field record is however beyond the scope of the present work, which deals with regional implications of major sedimentologic and stratigraphic characteristics of the Aptian succession in the RTJ.

\section{Geological background}

\subsection{Structural framework and deformation}

The RTJ stands out among the Cretaceous basins of northeastern Brazil for its great exposed area and stratigraphic thickness, being interpreted as an aborted branch of the Central South Atlantic Rift System (e.g. Matos, 1992, 1999; Milani et al., 2007). Each basin of the RTJ presents an asymmetrical half-graben geometry and is bounded by accommodation zones that locally separate sub-basins with opposite master fault dip directions, such as the North and Central Tucano sub-basins. These rift segments are separated by the Vaza Barris Accommodation Zone, which is bounded to the north by the Caritá Fault.

Basin border faults of the North and Central Tucano sub-basins respectively dip to SE (São Saité Fault) and NW (Adustina Fault) (Figs. 1 and 2). The basin border faults of the South Tucano Subbasin (Inhambupe Fault) and the Recôncavo Basin (Salvador Fault) dip to NW, whereas the border fault of the Jatobá Basin (Ibimirim Fault) dips to SSE (e.g. Milani and Davison, 1988) (Fig. 1). The RTJ master faults bound depocenters locally more than $10 \mathrm{~km}$ deep, such as the Cícero Dantas Low in the Central Tucano Sub-basin, and between 5 and $8 \mathrm{~km}$ deep elsewhere (e.g. Aragão and Peraro, 1994). A relationship between the Aptian deposits and depocenters in the RTJ can be observed in an N-S profile (A-A' in Figs. 1 and 2): the Aptian units are synformally deformed over the depocenters, probably due the differential compaction.

Although some authors indicate local coverage of master faults by the Marizal Formation (e.g. Gava et al., 1983 [in the North Tucano Sub-basin]; Magnavita et al., 2003; Dantas and Filho, 2006), the present day spatial distribution of the unit is constrained by the basin border faults (e.g. Viana et al., 1971; Gava et al., 1983 [in the Jatobá Basin]; this work) (Fig. 1), suggesting an Early Cretaceous structural inheritance for the accommodation space generated during the Aptian.

A supposed lack of brittle deformation of the Marizal Formation compared to the pre-Aptian deposits is also advocated by some 


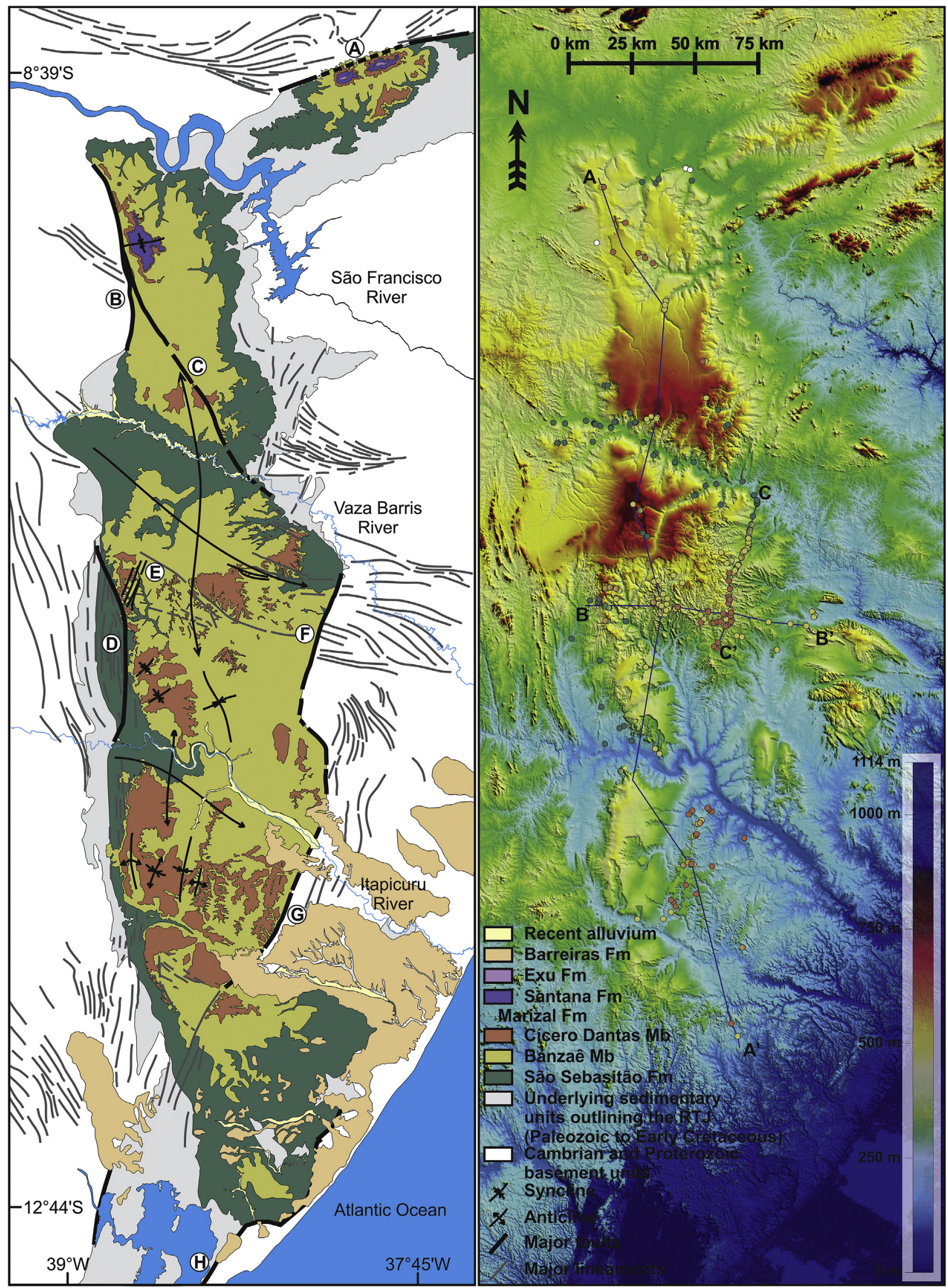

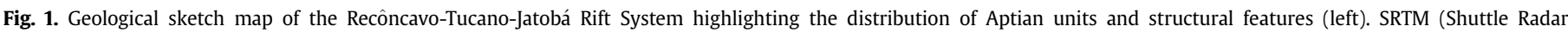

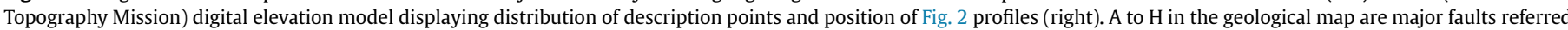

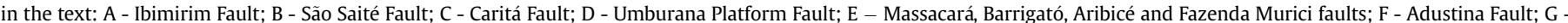
Inhambupe Fault; $\mathrm{H}$ - Salvador Fault. 
A
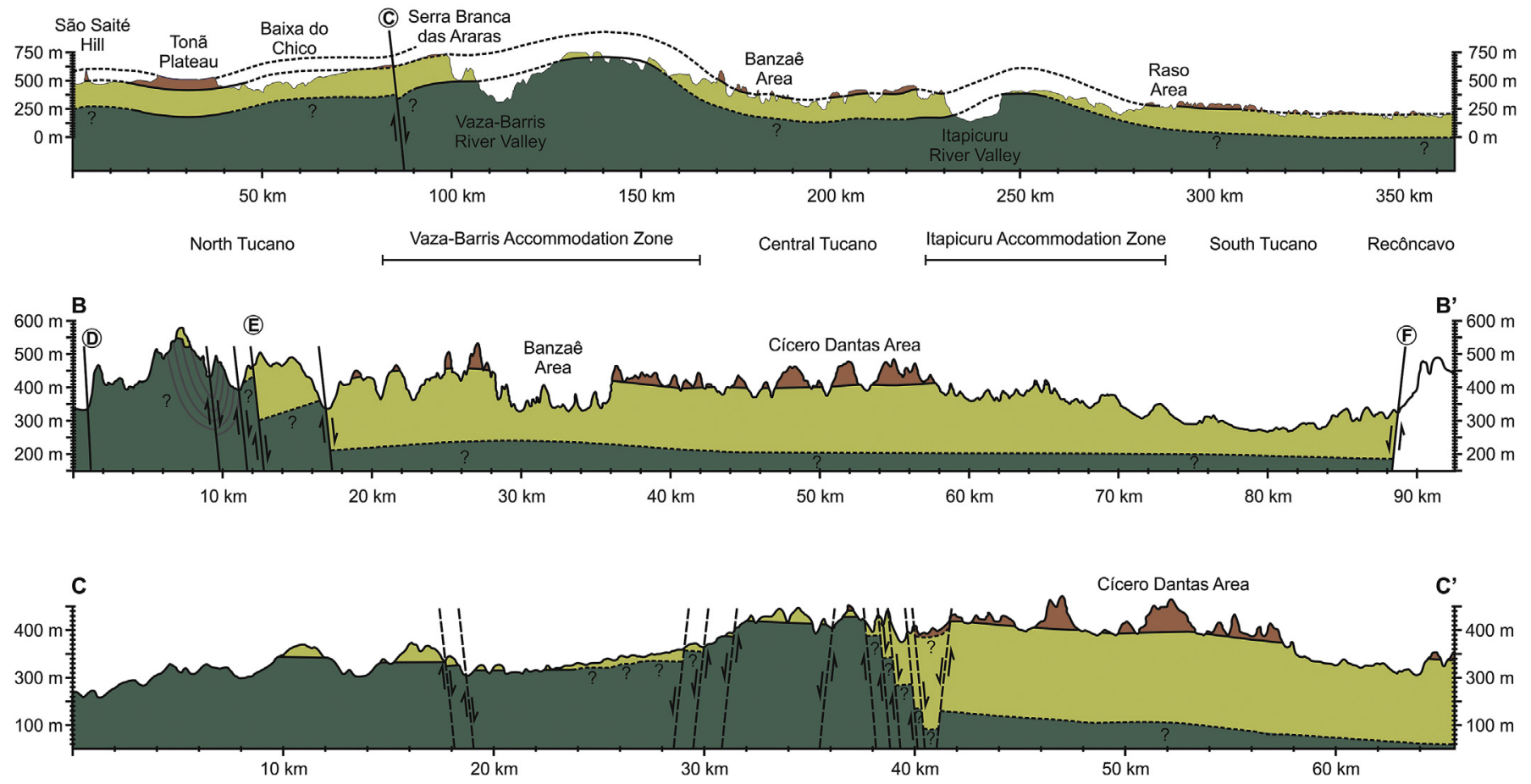

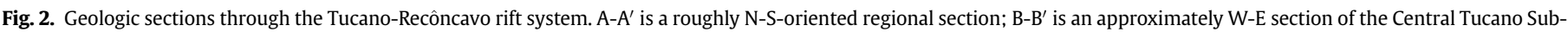

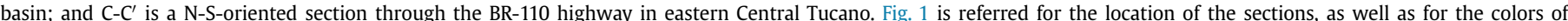

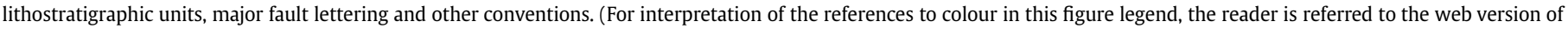
this article.)

authors (e.g. Destro et al., 2003; Vasconcellos, 2003). However, Aptian deposits were completely removed by erosion from the areas where the pre-Aptian deposits are more intensely deformed, commonly displaying shear bands, over the accommodation zones. On the other hand, deposits of the Marizal Formation can be locally observed overlying faults (shear bands) and folds deforming underlying units.

Other major deeply rooted structural features of the Tucano Basin whose activity was previously interpreted to be restricted to pre-Aptian times are the Caritá and Jeremoabo transfer faults, as well as the Umburana Platform Fault (e.g. Magnavita, 1992; Vasconcellos, 2003; Destro et al., 2003) (Figs. 1 and 2). However, the precise match of the Caritá Fault outline with a topographic lineament on the Aptian cover of the North Tucano and the coincidence of the western limit of the occurrence of the Marizal Formation in the Central Tucano with the Umburana Platform Fault (Fig. 1) both suggest a longer-lived activity for these features.

Additionally, recent geological mapping of the Central Tucano by the Geological Survey of Brazil (Santos et al., 2010; Santos and Reis, 2011) showed kilometer-scale long, NE-oriented, normal faults affecting the Marizal Formation in the western part of that sub-basin. These are the Massacará, Barrigató, Aribicé and Fazenda Murici faults (Figs. 1 and 2), and their NE trend matches the conspicuous N-S- and NE-SW-oriented shear bands deforming the preAptian deposits in the Vaza Barris River Valley (e.g. Destro et al., 2003; Vasconcellos, 2003).

Indeed, many faults were observed in the Marizal Formation throughout the Tucano Basin by the authors of the present work. Similar to the faults in pre-Aptian units (e.g. Magnavita, 1992; Destro et al., 2003; Vasconcellos, 2003), these are also characterized by centimeter to decimeter thick shear bands, dominantly with down-dip displacements, and local occurrence of steeply dipping bedding planes. Abundant small faults with normal to oblique centimeter-scale displacements in the Marizal Formation were also documented in the Recôncavo Basin by Lima and Vilas Boas (2000).

\subsection{Lithostratigraphy}

The clastic-dominated Aptian sedimentary succession in the RTJ is ascribed to the Marizal Formation (e.g. Magnavita et al., 2003; Silva et al., 2007; Costa et al., 2007a,b; Santos et al., 2010), and is locally overlain by the carbonate-bearing successions preserved in the North Tucano Sub-basin, specifically in the Serra do Tonã area, and in the Jatobá Basin, precisely in the Serra Negra and Serra do Periquito. The latter successions have been referred to with local names or as lithostratigraphic units described in the Araripe Basin, some $200 \mathrm{~km}$ to the north-northwest, which are at least in part dated as Albian (e.g. Braun, 1966; Rolim, 1984; Bueno, 1996; Almeida Filho et al., 2002; Rocha, 2011).

The carbonate-bearing successions of the Serra do Tonã (North Tucano), Serra Negra and Serra do Periquito (Jatobá Basin) areas were correlated by Braun (1966) to each other and to the Santana Formation (currently Santana Group, e.g. Assine et al., 2014) of the Araripe Basin, famous by its well-preserved fossils. In the same way, the overlying clastic deposits in the Jatobá Basin were ascribed to the Exu Formation, whose type section is in the Araripe Basin.

The Aptian age of the Marizal Formation is based on its fossil content. It was chiefly determined by the studies of palynomorphs (e.g. Gava et al., 1983; Viana et al., 1971; Almeida Filho et al., 2002; Reis et al., 2007), fishes (e.g. Silva Santos, 1972; Brito and AlvaradoOrtega, 2008; Alvarado-Ortega and Brito, 2010; Amaral and Brito, 2012), and ostracods (e.g. Gava et al., 1983; Almeida Filho et al., 2002). 
The Aptian deposits in the RTJ were initially described by Brazil (1947 apud BRASIL, 1948) in the Central Tucano Sub-basin. The author recognized two distinct lithostratigraphic units: one in the Serra do Marizal area, composed of a widely distributed basal conglomerate overlain by medium to coarse-grained cross-bedded sandstone, locally conglomeratic or micaceous, and another, near the town of Cícero Dantas, composed of reddish interstratified sandstone, siltstone and shale with minor intercalated conglomerate.

In the first published lithostratigraphic review of the RTJ, Viana et al. (1971) formally grouped the units formerly recognized by Brazil (1947 apud BRASIL, 1948) in the Marizal Formation, mentioning its occurrence in the entire RTJ and also in the Mirandiba Basin, a small basin between the RTJ and the Araripe basins. Viana et al. (1971) reported varied thicknesses for the Marizal Formation, with nearly $50 \mathrm{~m}$ in the Recôncavo Basin and up to $300 \mathrm{~m}$ in the Tucano Basin.

The Marizal Formation has been described as a sandstone dominated unit with local occurrences of conglomerate dominated successions and fossil bearing shales with scarce gypsum, bitumen and dense mudstone with barite intercalations (e.g. Viana et al., 1971; Silva Santos, 1972, Gava et al., 1983; Santos et al., 2010; Santos and Reis, 2011). Lateral facies variations characterized by the westward fining of thick conglomerate deposits in the eastern Central Tucano and an overall, more subtle, fining from the northern to the southern occurrences of the Marizal Formation in the Tucano Basin were reported by Gava et al. (1983).

However, a conglomerate-dominated succession with minor mudstone, sandstone and intercalated carbonate, cropping out along the eastern margin of the Central Tucano Sub-basin, and containing trace fossils and fishes (Brazil, 1947 apud BRASIL, 1948) as well as pelecypod coquinas (Gava et al., 1983), was named Poço Verde Formation and supposed to be older than the Marizal Formation (Brazil, 1947 apud BRASIL, 1948; Gava et al., 1983).

Deposits of the original Poço Verde Formation were recently mapped as Salvador Formation (Santos et al., 2010; Santos and Reis, 2011), an unit described as a pre-Aptian conglomerate succession in the Recôncavo Basin, reinforcing an stratigraphic position underneath the Marizal Formation. Nonetheless, recent provenance analysis carried out by Figueiredo et al. (2016) in conglomerate and conglomeratic sandstone deposits of this unit (referred to as Poço Verde Conglomerate by Figueiredo et al., 2016), of the Marizal Formation and of the underlying pre-Aptian fluvial deposits of the São Sebastião Formation suggested that the above referred conglomerate-dominated unit is coeval with the Marizal Formation if not the same unit (see below).

The Marizal Formation in the Recôncavo Basin was studied by Lima and Vilas Boas $(1994,2000)$ who performed facies and architectural element analysis in sandstone and conglomerate deposits. They recorded reduction in grain size from south to north, i.e. basinward from the NE-SW oriented fault scarps to the south, with the dominance of interpreted gravel-grade sediment gravity flow elements in the south and of sandy fluvial bar elements to the north. Mudstone-dominated successions up to $3 \mathrm{~m}$ thick seem to form a broad cover, interpreted from preserved patches in an up to $400 \mathrm{~km}^{2}$ area, over the gravelly and sandy elements. Dark laminated shale can be observed in a nearby area above an up to $5 \mathrm{~m}$ thick conglomerate succession with subordinated sandstone overlying deformed deposits of the pre-Aptian Cinzento mud diapir (Magnavita et al., 2005).

The Marizal Formation deposits have been mainly interpreted as continental deposits dominated by alluvial processes in fluvial and alluvial-fan depositional systems with the local development of minor lacustrine systems (e.g. Brazil, 1947 apud BRASIL, 1948; Viana et al., 1971; Gava et al., 1983; Magnavita and Cupertino, 1988; Milani and Davison, 1988; Lima and Vilas Boas, 1994, 2000; Magnavita et al., 2003, 2005; Costa et al., 2007a,b). The dominant fluvial deposits were interpreted as derived from a major trunk river flowing southward within the N-S oriented Tucano Basin, based on local paleocurrent data (e.g. Rolim and Mabesoone, 1982; Lima and Vilas Boas, 2000; Assine, 1994; Santos et al., 2010; Santos and Reis, 2011). The bulk of the studies on the Santana Group carbonate-bearing successions in the RTJ have interpreted the carbonate deposits as products of lacustrine depositional systems (e.g. Neumann et al., 2010; Tomé and Lima Filho, 2010; Santos et al., 2011; Varejão et al., 2016).

As a conclusion, the Marizal Formation is a well-established lithostratigraphic designation for the Aptian siliciclasticdominated succession of the RTJ. The carbonate-dominated top succession of the Tonã Plateau is here referred to as the Crato Formation of the Santana Group, considering the precedence of the proposition of Braun (1966) and modern usage (e.g. Neumann and Rocha, 2013; Neumann et al., 2013; Silveira et al., 2014; Assine et al., 2014; Varejão et al., 2016).

Together with the Exu Formation in the Jatobá Basin, the Marizal Formation and the Crato and Romualdo formations of the Santana Group are the remainders of the RTJ post-Aptian-unconformity tectono-sedimentary record. Thus, the detailed description and integrated interpretation of this sedimentary units are an important step in unraveling the complexities of the geological evolution of the W-Gondwana and Central South Atlantic during the Cretaceous.

\subsection{Geodynamic models}

Interpretations on the geodynamic significance of the Marizal Formation usually rely on its separation from the underlying deposits through an erosional and locally angular unconformity, implying in contrasting tectonic controls for the units above and beneath it. Accordingly, the unit was formerly considered as postrift deposits without the implication of the thermal subsidence predicted in the McKenzie (1978) model, and thus interpreted as the filling of a remnant topography following the cessation of tectonic activity (e.g. Netto and Oliveira, 1985; Magnavita and Cupertino, 1987, 1988; Milani and Davison, 1988; Menezes Filho et al., 1988). Regional tectonic interpretations based on gravimetric data applied the simple shear models of Wernicke (1985) and Lister et al. (1986) to the RTJ (e.g. Ussami, 1986; Castro, 1987), sustaining the lack of a thermal subsidence phase in the RTJ due to the lateral shift of the asthenosphere uplift to the breakup position farther east.

Based on vitrinite reflectance data, Magnavita et al. (1994) returned to the McKenzie (1978) model, interpreting the erosion of a more than $2 \mathrm{~km}$ thick post-rift pile in the RTJ, of which the Marizal Formation would be the remainder. This model was later supported by apatite fission track analysis (Japsen et al., 2012) and became a common view for the Marizal Formation (e.g. Magnavita et al., 2003, 2005; Milani et al., 2007), despite the restricted mention of syn-sedimentary fault activity (e.g. Petri, 1987; Caixeta et al., 1994; Magnavita et al., 2000; Figueiredo et al., 2016) and the advance of the syn-rift sag models (e.g. Karner and Driscoll, 1999; Marton et al., 2000; Karner et al., 2003; Huismans and Beaumont, 2008, 2011; Aslanian et al., 2009; Unternehr et al., 2010; Chaboureau et al., 2013).

\section{Results}

Detailed sedimentologic and stratigraphic studies together with a comprehensive review of previous works enabled the subdivision of the Marizal Formation in two main units, proposed here as 
members of the Marizal Formation. These sedimentary units are separated by a regional scale erosional surface locally cutting a fossiliferous marker bed (see below) preserved at the top of the lowermost unit. The proposed members of the Marizal Formation are the lower Banzaê Member, well exposed near the Banzaê town (Figs.1-3), and equivalent to the succession exposed in the Serra do Marizal area (e.g. Viana et al., 1971); and the upper Cícero Dantas Member equivalent to the abandoned term Cícero Dantas Formation of Brazil (1947 apud BRASIL, 1948) and well exposed near Cícero Dantas town (Figs. 1-3).

The lithological contrast between the Banzaê and Cícero Dantas members is commonly expressed in the topography, with the lower sandier, coarser-grained unit being related to steep-faced, flattopped cliffs and plateaus, and the latter deeply weathered, reddish, finer-grained unit being related to rounded cliffs with more gently dipping scarps (Fig. 4). These geomorphological characteristics often delineate two-stepped hill profiles, with a lower steep scarp related to the Banzaê Member, a flat sub-horizontal surface related to the basal contact of a fine-grained, fossiliferous marker bed between the two members, and rounded to locally scarped higher hills on top of that surface related to the Cícero Dantas Member.

The Cícero Dantas Member is commonly mistaken for Cenozoic covers on geological maps (e.g. Souza et al., 2003; Santos et al., 2010; Santos and Reis, 2011) probably due to its higher weathering susceptibility, giving rise to erodible materials resembling uncompacted sediments. The marker bed separating the Banzaê and Cícero Dantas members is laterally continuous for the entire Tucano Basin and part of the Recôncavo Basin, and was named Amargosa Bed after the Amargosa Village, Euclides da Cunha-BA municipality (Figs. 1-3).

The Amargosa Bed is a decimeter to meter-scale thick muddominated (Fig. 3) laterally continuous sedimentary unit recognizable across the entire Tucano Basin and even in the north of the Recôncavo Basin. It is characterized by a profuse and diversified fossil record, contrasting with the virtually fossil barren Banzaê and Cícero Dantas members. The Amargosa Bed bears the rich ichthyofauna of the Marizal Formation (e.g. Silva Santos, 1972; Figueiredo, 2004; Brito and Alvarado-Ortega, 2008; AlvaradoOrtega and Brito, 2010; Amaral and Brito, 2012).

A detailed sedimentological appraisal of the Banzaê and Cícero Dantas members is given below, followed by a discussion on the factors that control the preserved stratigraphic architecture and on paleogeographical implications of the stratigraphic refinement of the Aptian succession in the RTJ.

\subsection{The Banzaê Member depositional systems}

The Banzaê Member is a sandstone sheet, up to $200 \mathrm{~m}$ thick, found in the entire Tucano Basin (Figs. 1 and 2). It is superbly exposed in the center of the Central Tucano Sub-basin near the town of Banzaê, where individual outcrops are often closely spaced and comprised of tens of meters high sandstone walls laterally continuous for hundreds of meters, allowing precise lateral correlations for thousands of meters. In the Banzaê area, the upper $100 \mathrm{~m}$ section of the Banzaê Member is exposed within a gentle dome that is perceived by the radial dip of the topographically expressed contact surface between the Banzaê Member and the overlying Cícero Dantas Member.

The Banzaê Member is dominated by $2-6 \mathrm{~m}$ thick cross-strata cosets (compound cross-strata sensu Allen, 1982 and equivalent to macroscale inclined strata-set of Bridge, 1993, and 4th order units of Miall, 1996) laterally related to outsized foresets up to $6 \mathrm{~m}$ thick (Fig. 5). These cross-bedded cosets and laterally related outsized cross-strata are stacked in $15-25 \mathrm{~m}$ thick successions (multistorey sandstone bodies) bounded by decimeter to meterscale thick successions, characterized by small-scale cross-laminated sandstone, laterally related to planar and low-angle stratification, and minor heterolithic and mudstone beds. The latter successions are usually truncated by erosional surfaces commonly outlined by the presence of pebble to cobble-grade mudstone intraclasts. Paleocurrent measurements from cross-beds (up to 1200 measurements from tens of stations) present a mean direction to the south (Fig. 6).

In the eastern Central Tucano Sub-basin the Banzae Member is exposed on road cuts along the BR-110 highway between the towns of Cícero Dantas and Jeremoabo, comprising a more than $60 \mathrm{~km}$ long, N-S profile (C- $\mathrm{C}^{\prime}$ in Figs. 1 and 2). The contact with the underlying São Sebastião Formation is often exposed in the northern part of this geological section, and the contact with the Cícero Dantas Member regularly crops out in the southern part of the section. Between 30 and $40 \mathrm{~km}$ in the section, the Banzaê Member occurs locally as a few tens of meters thick succession intercalated amid the São Sebastião Formation and the Cícero Dantas Member (Fig. 2 C- $\mathrm{C}^{\prime}$ ). The Banzaê Member in the eastern Central Tucano is coarser-grained and often composed of rounded pebble and cobble-grade conglomerate derived from the nearby basement (e.g. Figueiredo et al., 2016).

The sandy facies are dominated by decimeter-scale thick trough cross-beds, whereas the gravelly deposits can be apparently massive, often imbricated and locally trough cross-bedded, with cross-bedded sets displaying decimeter to meter-scale thicknesses (Fig. 7 A). Plane-bedded, interstratified, roughly paired sandstone and conglomerate deposits can be locally observed (Fig. 7 B), as well as reddish fine-grained, decimeter to meter-scale thick successions, comprised of sandy heterolithic deposits, local mud beds with rare occurrences of fossil plant fragments and fine to medium-grained sandstone displaying small-scale cross-stratification (Fig. $7 \mathrm{C}$ to $G)$. Well-sorted sandstones, organized in sheets with intercalated large-scale cross-strata and thin mud beds occur restrictedly. Measured paleocurrents in the conglomeratic sandstone deposits display mean directions to W-SW and S-SE (Fig. 6), and the restricted fine-grained well sorted sandstone provides a northeastward mean direction (Fig. 6).

The successions constituted by the above described deposits laterally pass (to the east and southeast) into the conglomeratedominated unit, previously mapped as the Poço Verde Formation (see above), bordering the eastern basin-bounding fault (Figs. 1 and $\left.2 \mathrm{~B}^{-} \mathrm{B}^{\prime}\right)$. The conglomerate-dominated unit is comprised of inclined pebble to cobble-grade conglomerate beds or lenses intercalated with inclined plane-bedded pebbly sandstone (Fig. 8 A to F). Clast imbrication is commonly observed (Fig. 8 A, B, C and F), whereas boulder breccias, contorted laminated calcrete beds and crossbedded conglomerate are locally observed (Fig. 8 B, C, D and F). Santos et al. (2010) and Santos and Reis (2011) recorded westward paleoflow from clast imbrication in the conglomerate-dominated succession of the eastern Central Tucano.

In the western part of the Central Tucano Sub-basin, medium to coarse-grained sandstones ascribed to the Banzaê Member with subordinate mudstone and conglomerate beds (Fig. 9) occurs filling an immature erosional surface with tens of meters of unevenness a N-S oriented paleovalley - over the eastwardly tilted deposits of the São Sebastião Formation (Fig. 2 B-B'). These deposits are overlain by a distinctively bimodal and highly rounded fine to medium grained well sorted, large-scale cross-bedded sandstone succession up to $20 \mathrm{~m}$ thick, often displaying pin stripe lamination. A few hundreds of meters farther east, the upper fine to medium-grained sandstone deposits regularly overlie interbedded decimeter-scale thick sandstone and pebble to cobble-grade conglomerate beds (Fig. 9C). The sandstone beds present intraclastic mudstone 


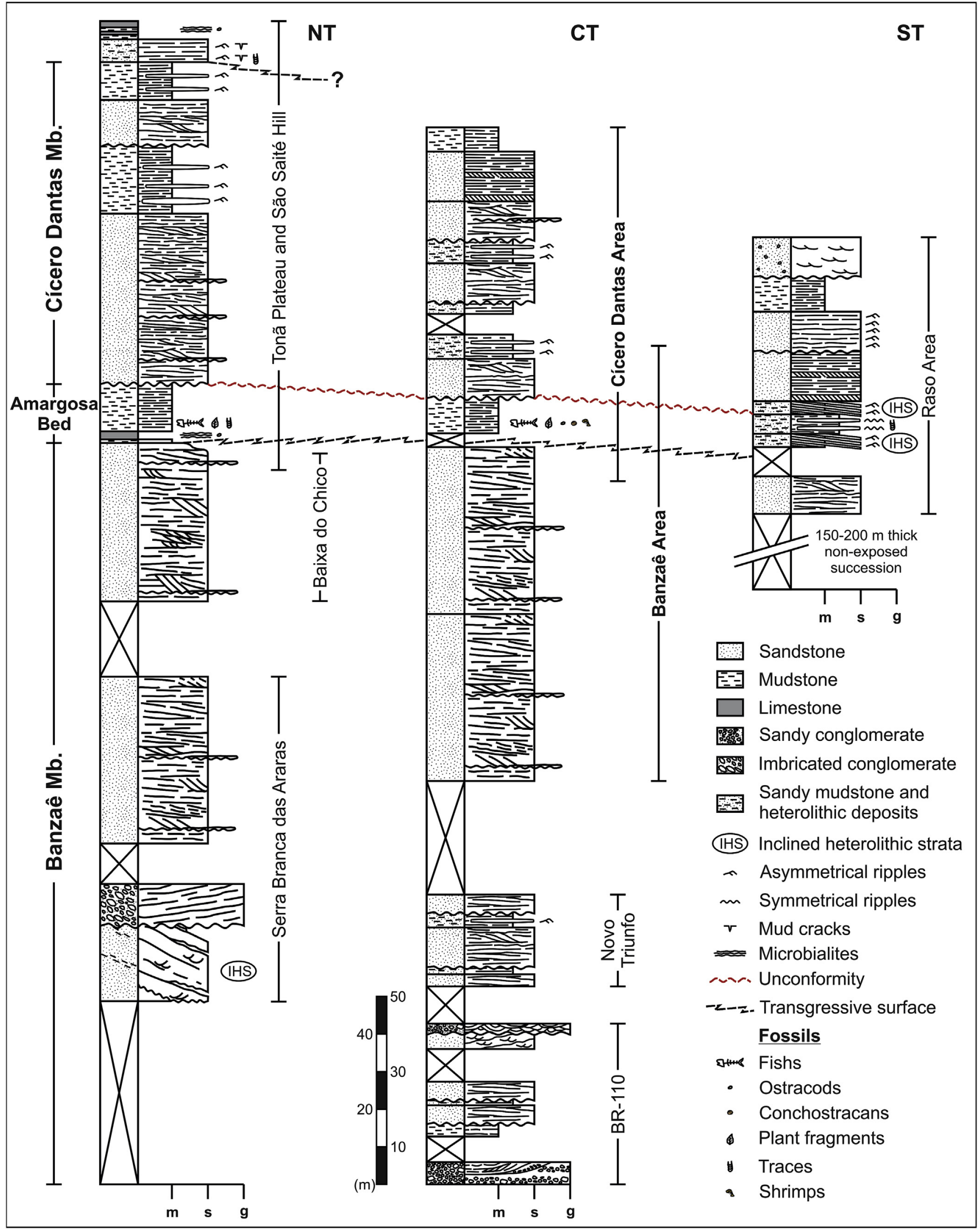

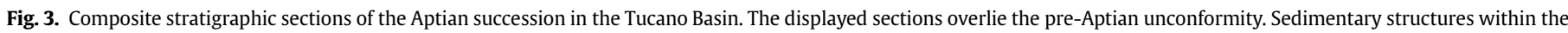

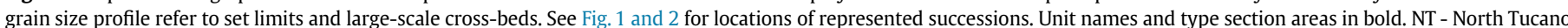
Sub-basin; CT - Central Tucano Sub-basin; ST - South Tucano Sub-basin. 

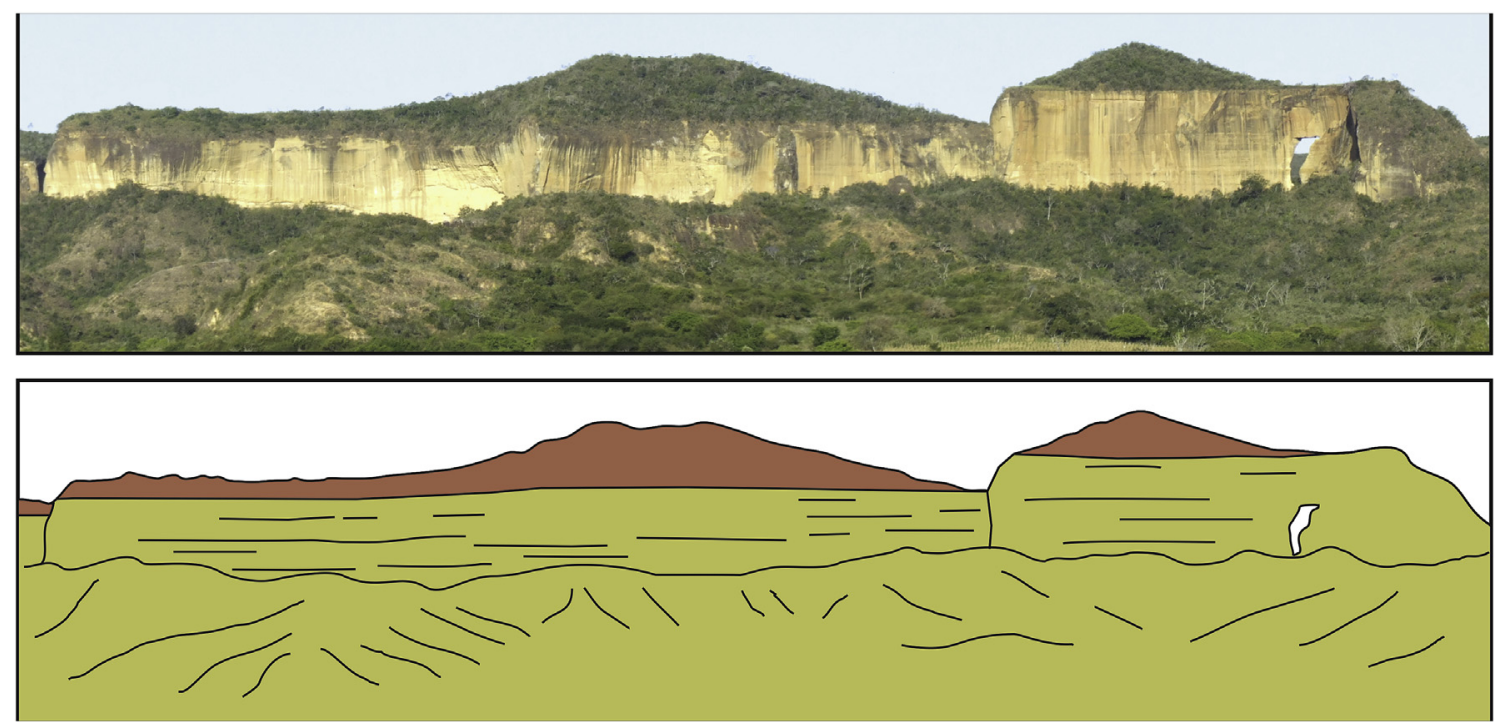

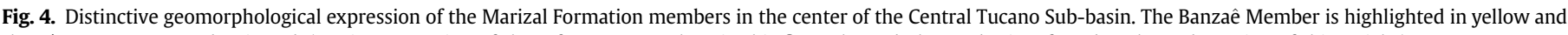
the Cícero Dantas Member in red. (For interpretation of the references to colour in this figure legend, the reader is referred to the web version of this article.)
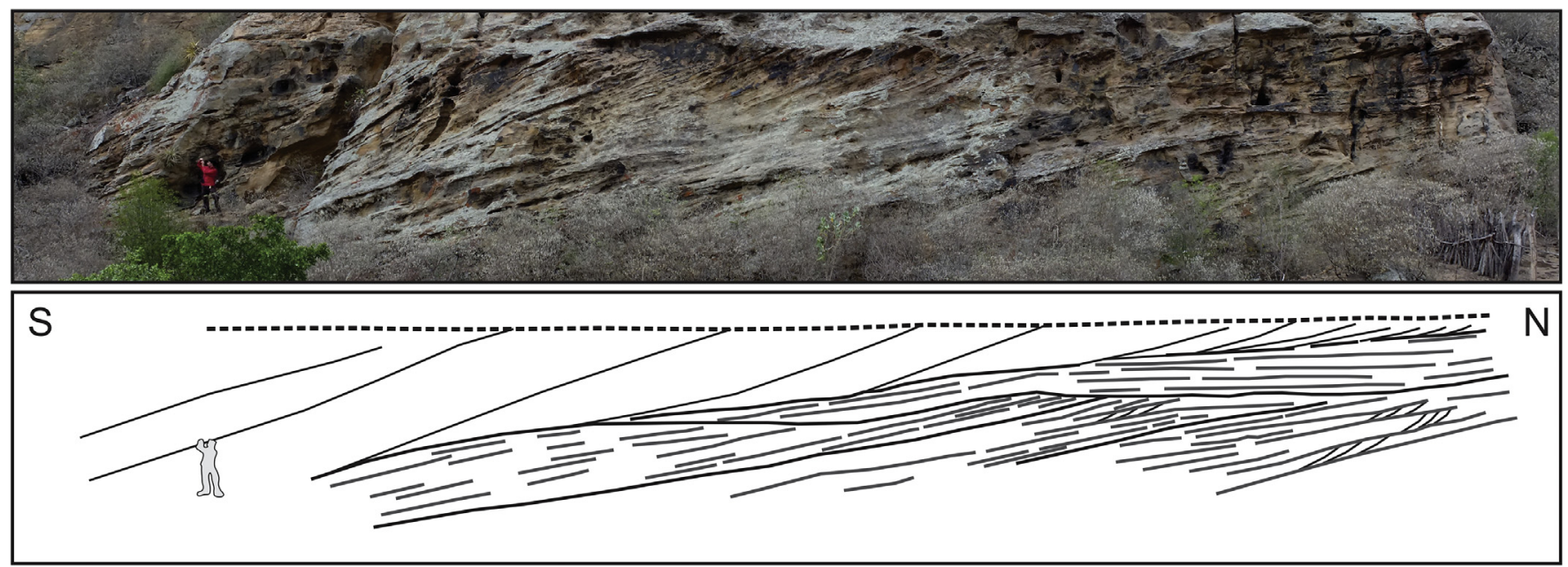

$\begin{array}{lll}\text { cross-strata } & & \text { cross-strata coset bounding surfaces } \\ \text { cross-strata bounding surfaces } & -1-- & \text { large-scale cross-strata/cosets bounding surfaces }\end{array}$

Fig. 5. Large-scale cross-strata and laterally related cross-strata cosets in the Banzaê Member. $1.8 \mathrm{~m}$ tall geologist for scale.

granules as well as mud cracks and mud curls (Fig. 9C and D). At the top, the large-scale cross-bedded well-sorted sandstone records a nearly northward paleoflow (Fig. 6).

In the North Tucano Sub-basin, the Banzaê Member is exposed in two areas: the Serra Branca das Araras area in the center of the southern limb of the sub-basin and in the very center of it, in the Baixa do Chico area (Fig. $2 \mathrm{~A}-\mathrm{A}^{\prime}$ ). In the Serra Branca das Araras, the entire section of the Banzaê Member crops out in several tens of meters high sandstone walls laterally continuous for hundreds to thousands of meters. The composite thickness of the exposed sandstone succession is approximately $200 \mathrm{~m}$ (Fig. $2 \mathrm{~A}-\mathrm{A}^{\prime}$ ). The Baixa do Chico area is a $12 \mathrm{~km}$ long, N-S oriented, nearly straight canyon with tens of meters high sandstone walls exhibiting the upper section of the Banzaê Member, whose facies associations and proportions are similar to those observed in the Banzae area in the central part of the Central Tucano Sub-basin (Fig. 5).

The succession in the Serra Branca das Araras area is marked by the presence of a particular facies association, constituted by largescale, tens of meters thick, sandy, inclined heterolithic strata (IHS), sensu Thomas et al. (1987), exposed on sandstone walls (Fig. 10A and B). Large-scale lenses, up to $6 \mathrm{~m}$ thick and laterally continuous for hundreds of meters, with concave-up bases and irregular tops, composed of reddish small-scale cross-laminated, fine-grained, sandy heterolithic deposits are locally intercalated within the inclined heterolithic strata succession (Fig. 10 B and D). These deposits are truncated by cobble to boulder-grade, imbricated, gravel deposits up to several meters thick above laterally continuous erosional surfaces with local high relief (Fig. 10 A to C). Paleocurrents measured from the IHS deposits reveal a marked eastward component, perpendicular to the northward dip of the large-scale sandy heterolithic stratification. This eastward paleocurrents were also observed in another paleocurrent station some $30 \mathrm{~km}$ to ENE (Fig. 6). At the Baixa do Chico area, a southward mean paleoflow direction was recognized (Fig. 6). 


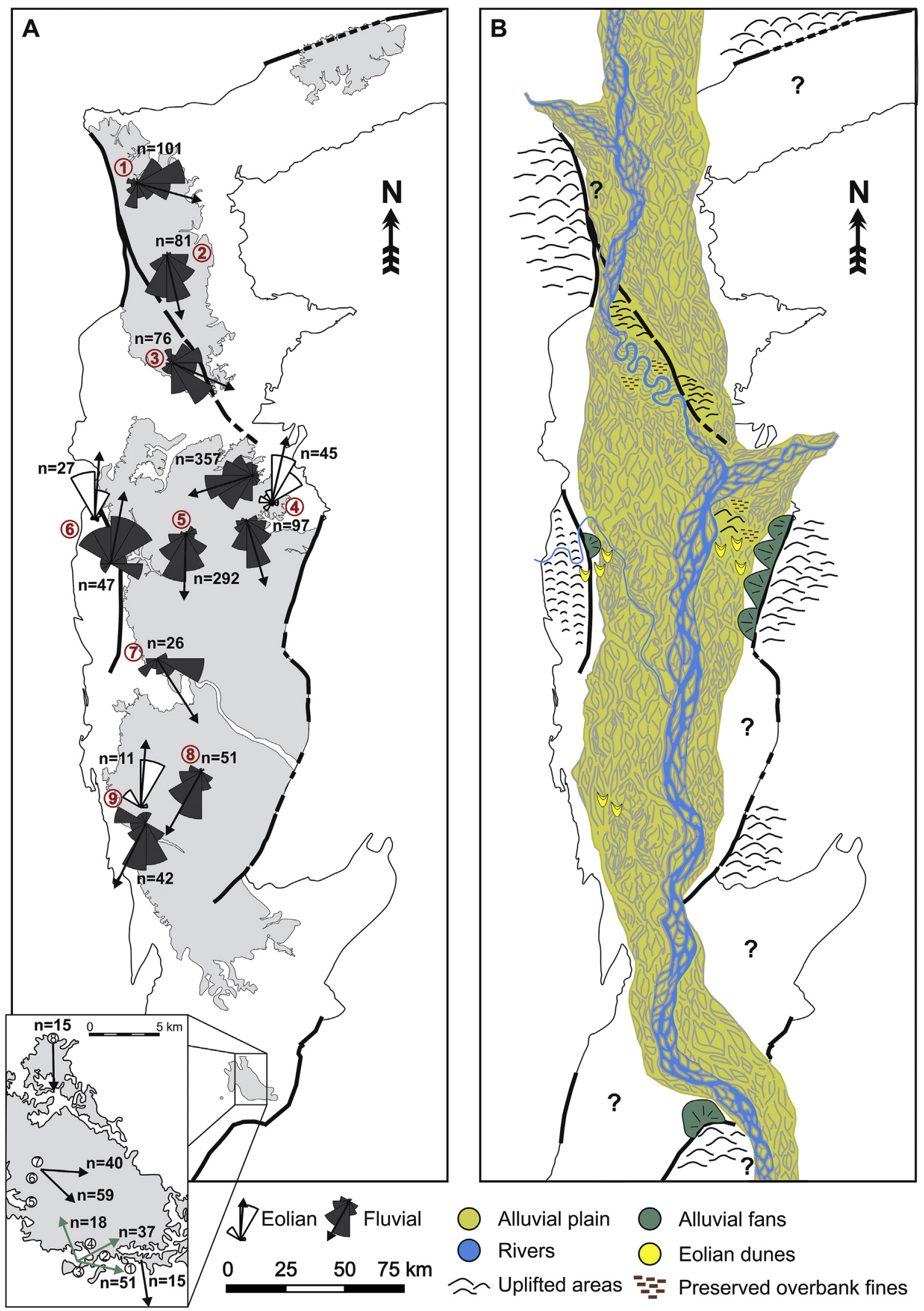

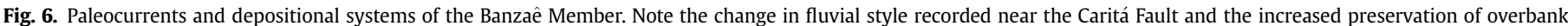

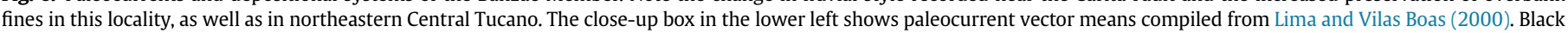

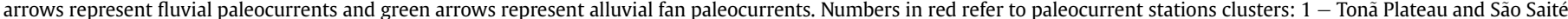

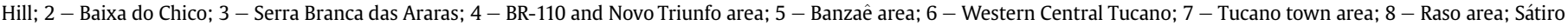
Dias area. (For interpretation of the references to colour in this figure legend, the reader is referred to the web version of this article.) 

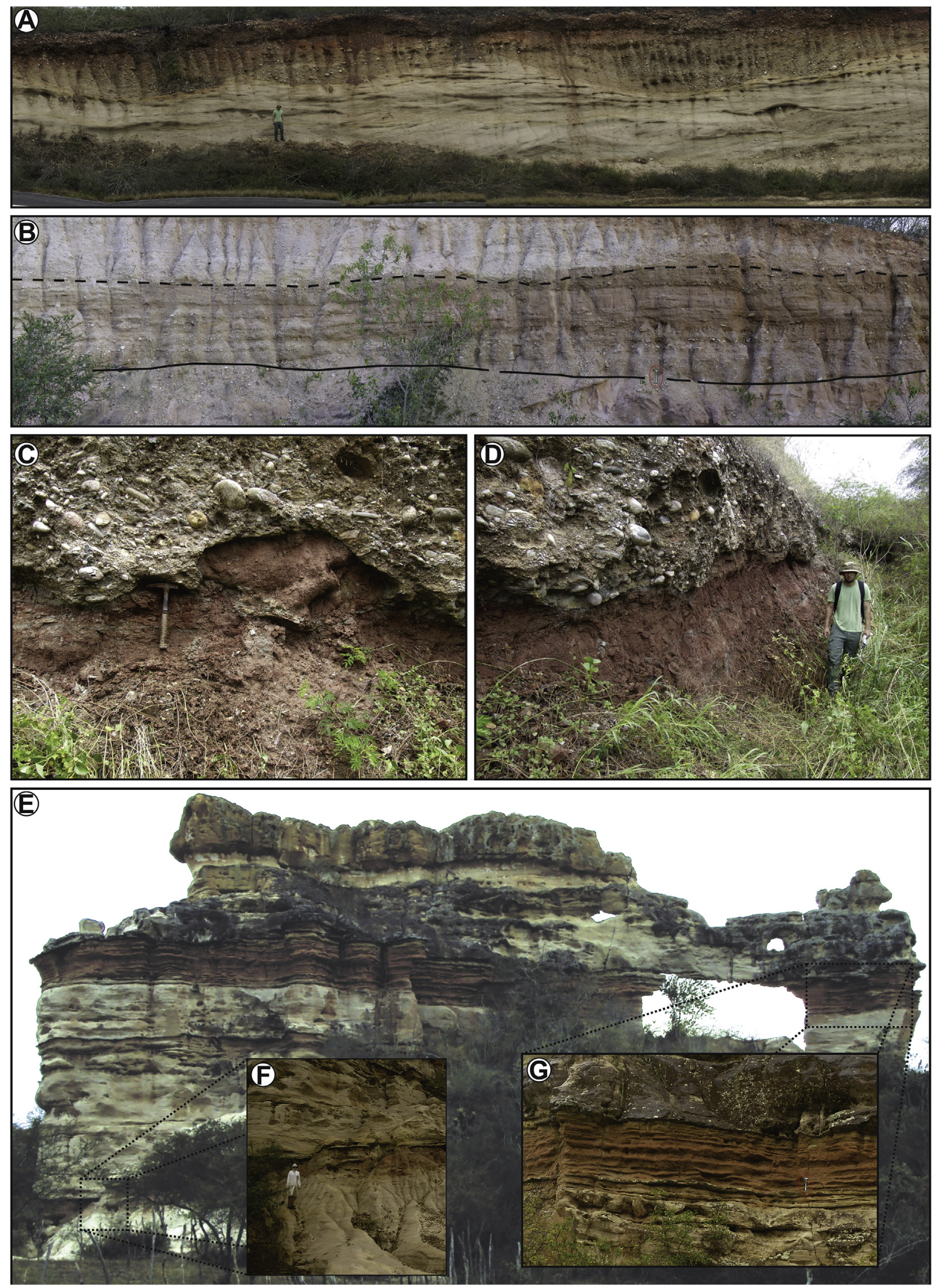

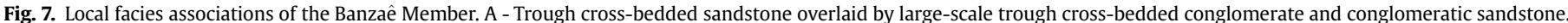

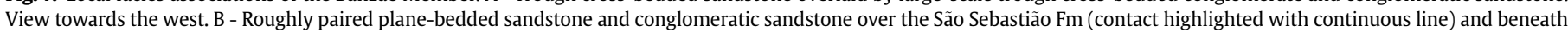

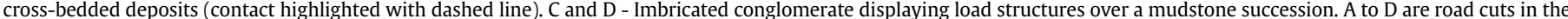

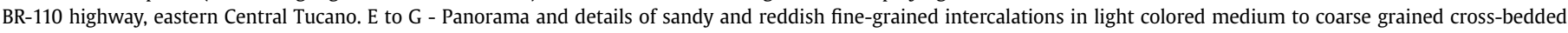
sandstone, Serra da Igrejinha, Novo Triunfo-BA, Central Tucano. 

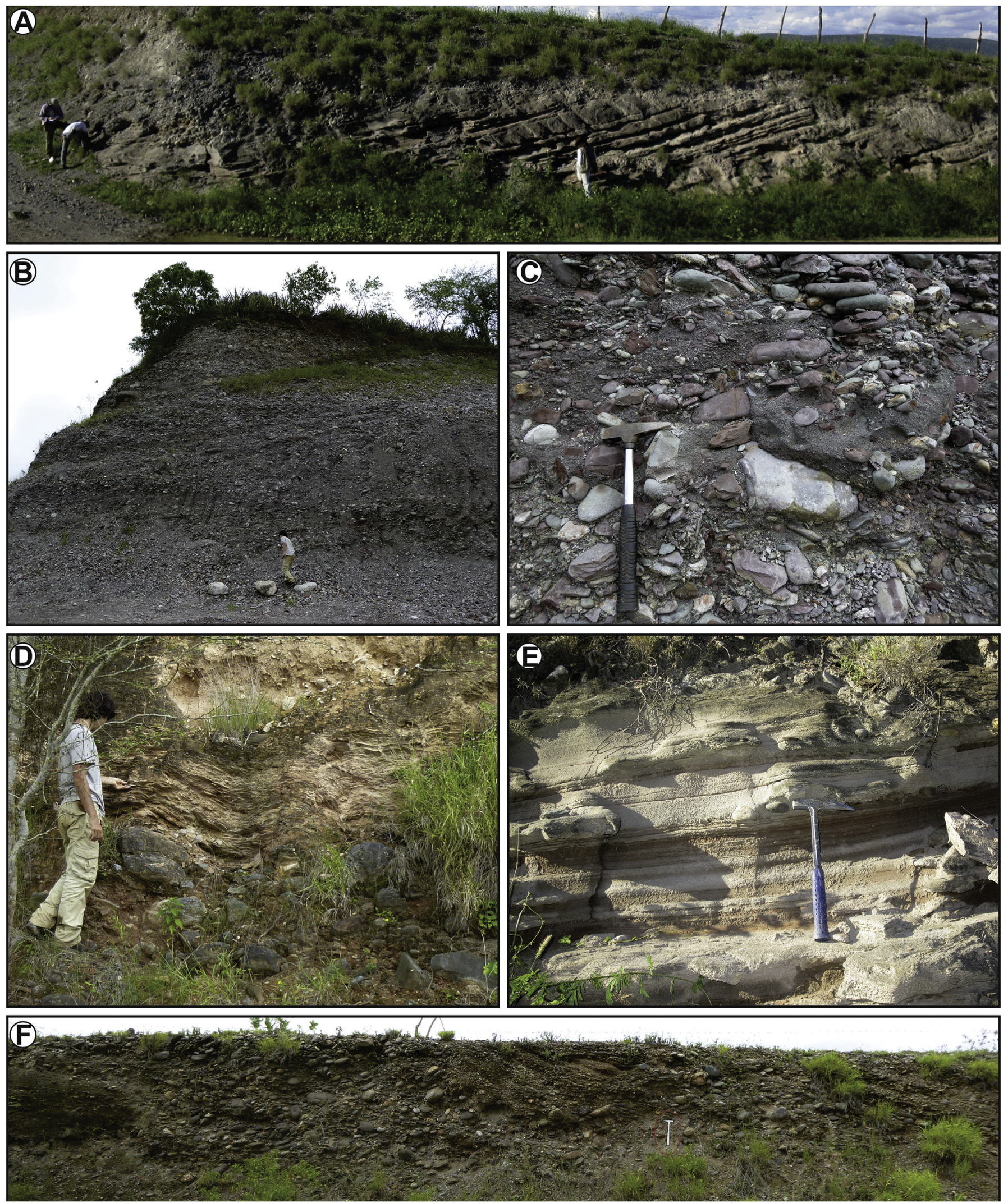

Fig. 8. Eastern Central Tucano conglomerate-dominated facies associations of the Banzaê Member. A - Inclined plane-bedded pebbly sandstone underlying a conglomerate succession (to the left). B - Conglomerate succession displaying meter-scale sets comprised of inclined beds roughly defined by the proportion of large gravel versus granules. C - Detail of the conglomerate succession displayed in B showing granule-dominated beds and coarser-gravel-dominated beds locally imbricated. D - Pebble to boulder-grade breccia composed of carbonate clasts overlaid by laminated and contorted calcrete. $\mathrm{E}$ - Detail of the inclined plane bedded sandstone beds displayed in A presenting fine-grained veneers and sparse pebbles. F - Imbricated and trough cross-bedded conglomerate deposits. 

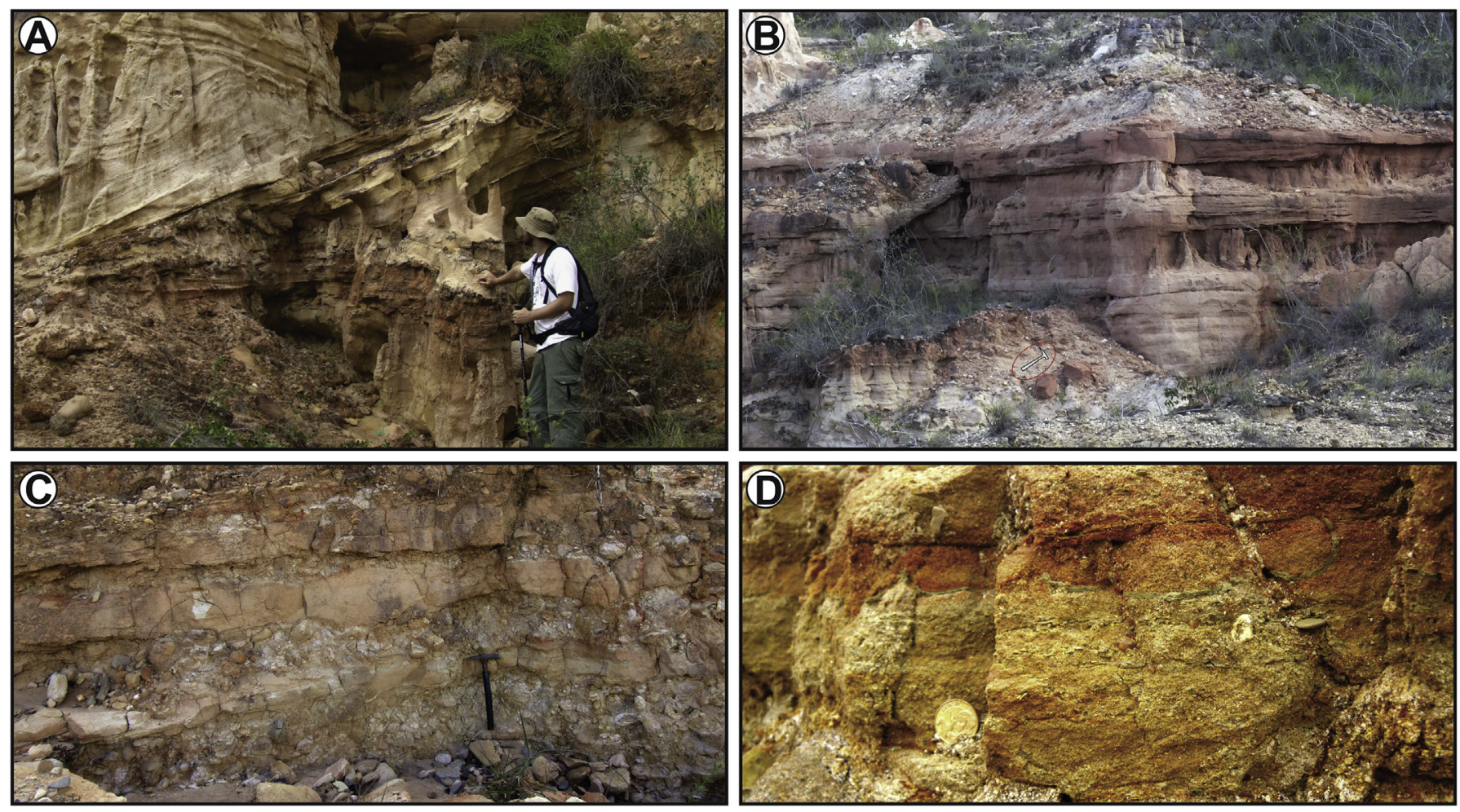

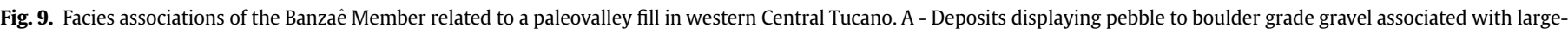

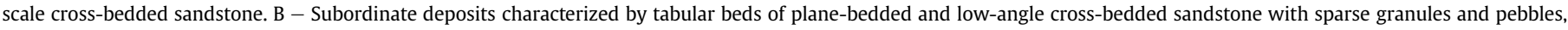

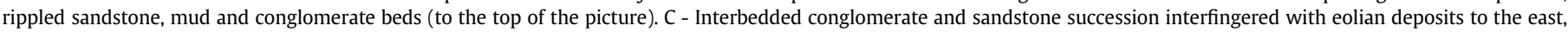
over the shoulder of the paleovalley. D - Close-up of mud curls in sandstone beds displayed in C.

In the South Tucano Sub-basin, the Banzaê Member is poorly exposed due to vegetation cover and topography base level. Outcrops of the unit usually show its upper section, which is characterized by contrasting facies associations: Pebbly medium to coarse-grained compound cross-bedded units are overlain by fine to medium-grained well-sorted sandstone displaying plane-beds, locally with parting lineation, small-scale climbing crosslamination, either subcritical or supercritical, isolated medium to large-scale cross-beds, and heterolithic deposits, locally inclined (Fig. 11). This upper facies association display highly variable, meter-scale, thicknesses. Paleocurrents measured in the coarsergrained deposits reveal a mean paleoflow to S-SW (Fig. 6).

In the Reconcavo Basin the bulk of the Marizal Formation was eroded, being the remnant deposits correlated to the lower section of the Banzaê Member (Figs. 1 and 2 A- $\mathrm{A}^{\prime}$ ). The northern occurrences of the Banzaê Member deposits in the Recôncavo Basin near the limit with the Tucano Basin (Fig. 1) are comprised of conglomeratic, cross bedded, quartz arenite, with granule and pebble composition dominated by vein quartz and quartzmylonite. Apparently intraclastic, sandstone pebbles with ferruginous cement also occur. Farther south, Lima and Vilas Boas (1994, 2000) described correlatable deposits in terms of six sandstone facies, five conglomerate facies and two mudstone facies. The conglomerate facies occur clustered at the south of the basin, where imbricated and cross-bedded deposits subordinated to massive facies provided NNW to ESE paleoflows. Cross-beds in sandy deposits point to S, SE and E paleocurrents (Lima and Vilas Boas, 1994, 2000) (Fig. 6).

\subsubsection{Interpretation}

The meter-scale thick compound cross-strata laterally related to outsized foresets are interpreted as compound thalweg dunes (Almeida et al., 2016b) and unit bar deposits, i.e. quasi- or nonperiodic, usually lobate, bedforms displaying lengths scaled to flow width and heights comparable to bankfull depth, and presenting a relatively simple architecture due to its strict depositional origin (e.g. Bridge, 2003; Sambrook Smith et al., 2006; Reesink and Bridge, 2007, 2009; 2011). These deposits stack to form 10-25 m packages bounded by relatively thin successions characterized by shallow water facies, here interpreted as bar top and floodplain deposits.

The preservation of bar tops and floodplain deposits bounding stacked thalweg and bar deposits can be ascribed to avulsions (e.g. Bristow, 1996; McLaurin and Steel, 2007). In this way, the sedimentary package bounded by avulsion surfaces is interpreted as a channel belt succession, i.e. the sediment piled during the construction of an alluvial ridge between avulsion events that steered the channel belt to the same position (e.g. Godin, 1991; Bristow, 1996; McLaurin and Steel, 2007). However, bar surface reconstructions from deposits of the Banzaê Member (Almeida et al., 2016a) suggest that channel belt deposits are not necessarily bounded by bar top and floodplain facies associations, implying a higher hierarchy, probably allogenic controlled, for the $10-25 \mathrm{~m}$ thick packages and their bounding surfaces and facies associations.

The dominance of these few tens of meters thick sand bodies comprised of meter-scale thick, southward accreted, amalgamated compound dunes and unit bars throughout a sandstone sheet approximately $200 \mathrm{~m}$ thick, $450 \mathrm{~km}$ long and up to $70 \mathrm{~km}$ wide, points to an origin mainly associated to a large-scale axial fluvial system for the Banzaê Member (Fig. 6). Despite the overall homogeneity of the Banzaê Member, significant variations in facies associations and paleocurrent patterns can be observed at some 

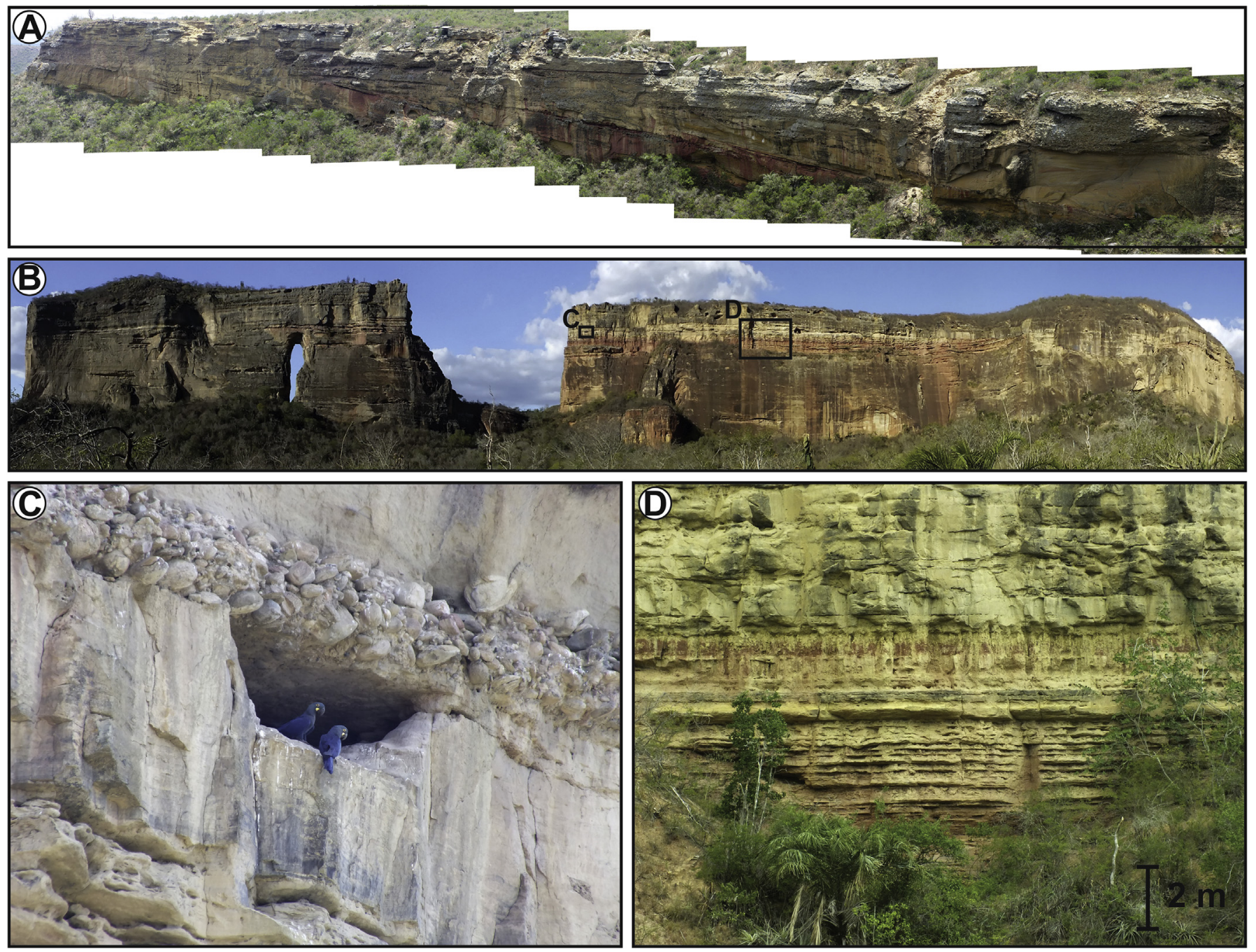

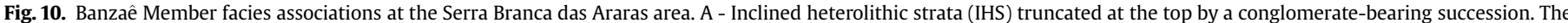

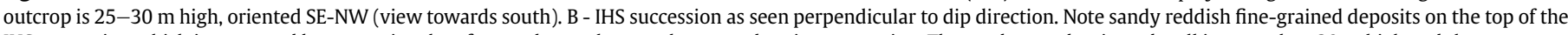

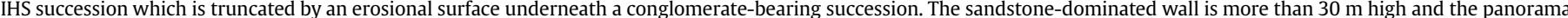

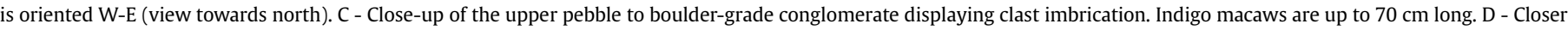
view of the sandy reddish rippled succession as exposed on the back side of the wall showed in $\mathrm{B}$.
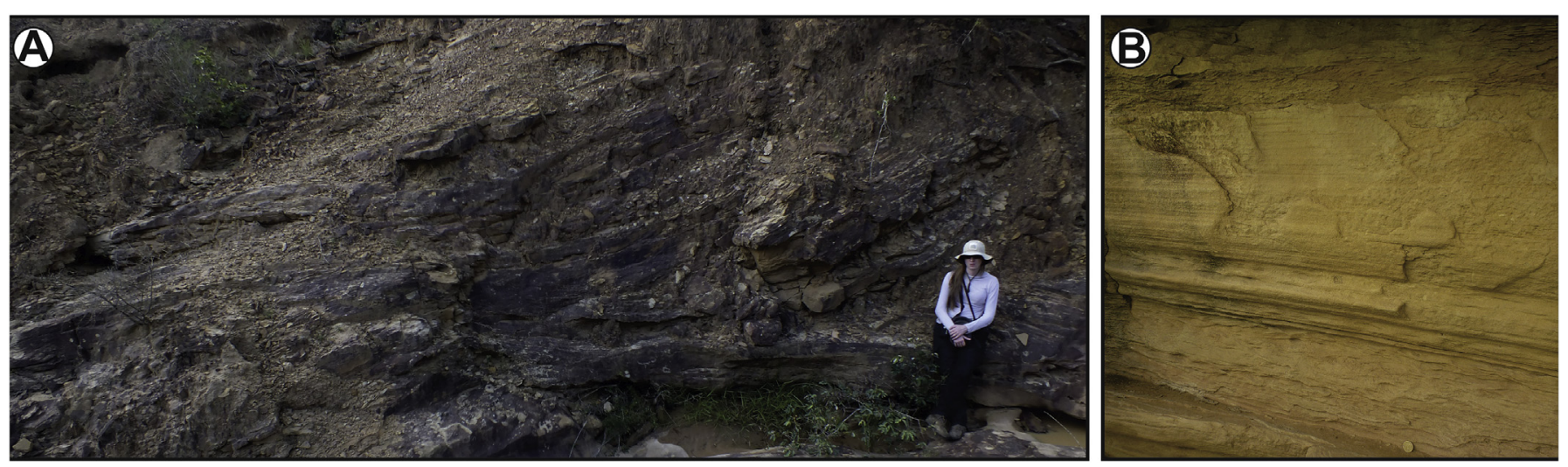

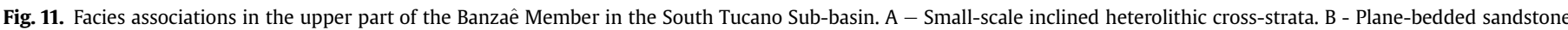
facies between subcritical climbing ripple packages at the top and base.

places. Among the striking heterogeneities of the unit is the distribution of conglomerate-dominated deposits. They occur in the middle Banzaê section at the Serra Branca das Araras area (centersouth of the North Tucano) and at the base of the unit in the eastern 
and western Central Tucano, and south of the Recôncavo Basin (Fig. 6). Their proximity with major structural features of the RTJ, respectively the Caritá, Adustina, Umburana Platform and Salvador faults, is noteworthy, being probably the product of fault scarp degradation and increased gradient related to fault-displacement uplift.

At the eastern Central Tucano, the occurrence of these conglomerate facies as massive lenses and wedges locally associated with plane-bedded pebbly sandstones and also as paired sandstone and conglomerate deposits are interpreted as alluvial fan deposits (Fig. 6), locally sheet flood dominated (sensu Blair \& McPherson, 1994; Blair, 1999), supporting the idea of fault scarp degradation during the sedimentation of the Banzaê Member. Locally, preserved imbricated conglomerate provide transverse paleoflow patterns as reported by Santos et al. (2010) and Santos and Reis (2011) in the eastern margin of the Central Tucano, where they mapped the conglomerate-dominated unit here ascribed to the Banzaê Member as Salvador Formation. Similar facies, dominated by massive and stratified conglomerates in the south of the Recôncavo Basin were also interpreted by Lima and Vilas Boas $(1994,2000)$ as alluvial fan deposits, spread from a southwestern basement high to NNW to ESE (Fig. 6).

In the eastern Central Tucano (northern part of the N-S C-C' profile in Fig. 2), cross-bedded conglomerate associated with crossbedded conglomeratic sandstone displaying W-SW paleocurrents is interpreted as a transverse fluvial system, sourced from the east (Fig. 6). Clast size-distribution and composition in these deposits contrast with the dominant axial fluvial facies, being more akin to the eastern fault-bounded alluvial fans (e.g. Figueiredo et al., 2016), what indicates a similar source area to the east corroborating the paleocurrent interpretation. S-SE paleocurrents in fluvial deposits a few kilometers farther south are interpreted as the result of the influence of a probably fault-bounded intrabasinal high, inferred in the $\mathrm{N}-\mathrm{S}$ geological profile in the BR-110 federal route (Fig. 2 C-C'), with diverting fluvial flow around it (Fig. 6).

Paleocurrent patterns also suggest sin-sedimentary fault activity of the Caritá Fault in the North Tucano Sub-basin, where the dominant fluvial facies association ascribed to a trunk river system displays fault-parallel southeastward paleocurrent patterns on both the hangin wall and footwall sides (Fig. 6). In this way, the Caritá Fault would have controlled a localized NW-trending watershed between the center and the southeast of the North Tucano. On the other hand, paleocurrent data from the Recôncavo Basin (Lima and Vilas Boas, 1994, 2000) (Fig. 6) indicate that the southward flowing trunk river captured in the RTJ flowed against the NE-SW fault-bounded basin border, being locally deflected around alluvial fan deposits, and thereby suggesting the basin border no longer acted as the topographic barrier active until Aptian times (Fig. 6).

Another tributary filling N-S-oriented paleovalleys, is interpreted from the deposits of the Banzaê Member in the western Central Tucano (Fig. 6). The N-S trend of the paleovalley is probably caused by the paleotopographic expression of the N-S striking and eastwardly tilted underlying deposits during the development of the angular unconformity between the São Sebastião and Marizal formations. The fluvial succession in this part of the basin is followed by the deposits of an eolian dune field, the thickest recognized in the Banzaê Member, interpreted from the well sorted and rounded, medium to large-scale cross-bedded fine to mediumgrained bimodal sandy deposits often displaying pin stripe laminations. The paired conglomerate and mud-curl-bearing sandstone beds laterally related to the eolian dune field are interpreted as the product of alluvial-eolian interaction probably related to alluvial fan settings. Minor occurrences of eolian dunes and interdunes are also interpreted in the eastern and southwestern Central Tucano, complementing the NNE paleowind record (Fig. 6).

Fine-grained facies associations constitute another relevant heterogeneity within the Banzaê Member sheet sandstone. These decimeter to meter-scale thick rippled, locally heterolithic or muddominated deposits intercalated within large-scale IHS in the Serra Branca das Araras area are interpreted as part of a large-scale meander-belt (e.g. Thomas et al., 1987) (Fig. 6) probably related to a tectonic forcing, given the proximity of all the sedimentological particularities observed in the area with the Caritá Fault. The more common occurrence of these fine-grained deposits intercalated in the amalgamated cosets succession in northeastern Central Tucano is interpreted as increased preservation of floodplain and bar top deposits controlled by higher subsidence rates (e.g. Bryant et al., 1995; Heller and Paola, 1996; Hickson et al., 2005) in the immediate hanging wall over the Cícero Dantas Low (Figs. 1 and 2).

Finally, the contrasting facies associations observed near the top of the Banzaê Member succession in the South Tucano are interpreted as the product of a northward driven transgression with coastal and eolian reworking over the fluvial deposits of the southward flowing axial river system. The common occurrence of thick rippled successions could thus be a product of enhanced frequency of channel abandonment in the channel belt and floodplain sub-environments due to increased channel shifting and/or local avulsion related to the adjustment of the equilibrium profile to the ongoing transgression. This scenario would explain the difference in sorting between both facies associations, the dominance of plane-beds and southward climbing ripples, the thickness variation noticed in the uppermost deposits, and the retrogradational architecture configured in the transition of the fluvial deposits into the Amargosa Bed.

\subsection{The Cícero Dantas Member depositional systems}

The Cícero Dantas Member is up to $100 \mathrm{~m}$ thick and is characterized by the occurrence of isolated relatively coarse-grained, cross-bedded sandstone bodies within finer-grained sandy and heterolithic facies (Fig. 12). The cross-bedded sandstone bodies include large-scale and relatively thin tabular bodies, whereas the enclosing deposits can be fine sandstone and sandy heterolithic deposits (Fig. 12). Both the enclosing and enclosed deposits of the Cícero Dantas Member are usually deeply weathered, displaying reddish colors and being better exposed in road cuts.

The fine-grained sandy successions, tabular at the outcrop-scale, encompass profuse small-scale, subcritical and supercritical climbing cross-lamination, as well as plane-bedded, fine to medium-grained, well-sorted sandstone, locally presenting parting lineation or associated with medium to large-scale cross-beds. This facies association presents thickness of several meters and typically occurs near the base of the Cícero Dantas Member, being better developed (or exposed) in the South Tucano Sub-basin. At some places, including a stratigraphically higher occurrence in the Central Tucano Sub-basin, the facies association lacks the small-scale cross-lamination and is comprised of fine to medium-grained, plane-bedded, well-sorted sandstone with isolated medium to large-scale cross-beds (Fig. 13). Paleocurrents are generally southward, with mean vectors varying from SW to SE and NW (Fig. 14).

The heterolithic facies usually present tabular geometries at the outcrop scale, are sand-prone and organized in interbedded, meterscale thick packages comprised of fine to very fine-grained micaceous sandstones with locally preserved ripples, massive to faintly laminated very fine sandstone and siltstone, as well as argillaceous mudstones locally presenting horizontal lamination and plant remains. Centimeter to decimeter-scale thick lenses of small to medium-scale cross-bedded sandstone can also occur, and locally display trough cross-beds at the base, transitioning towards the top 

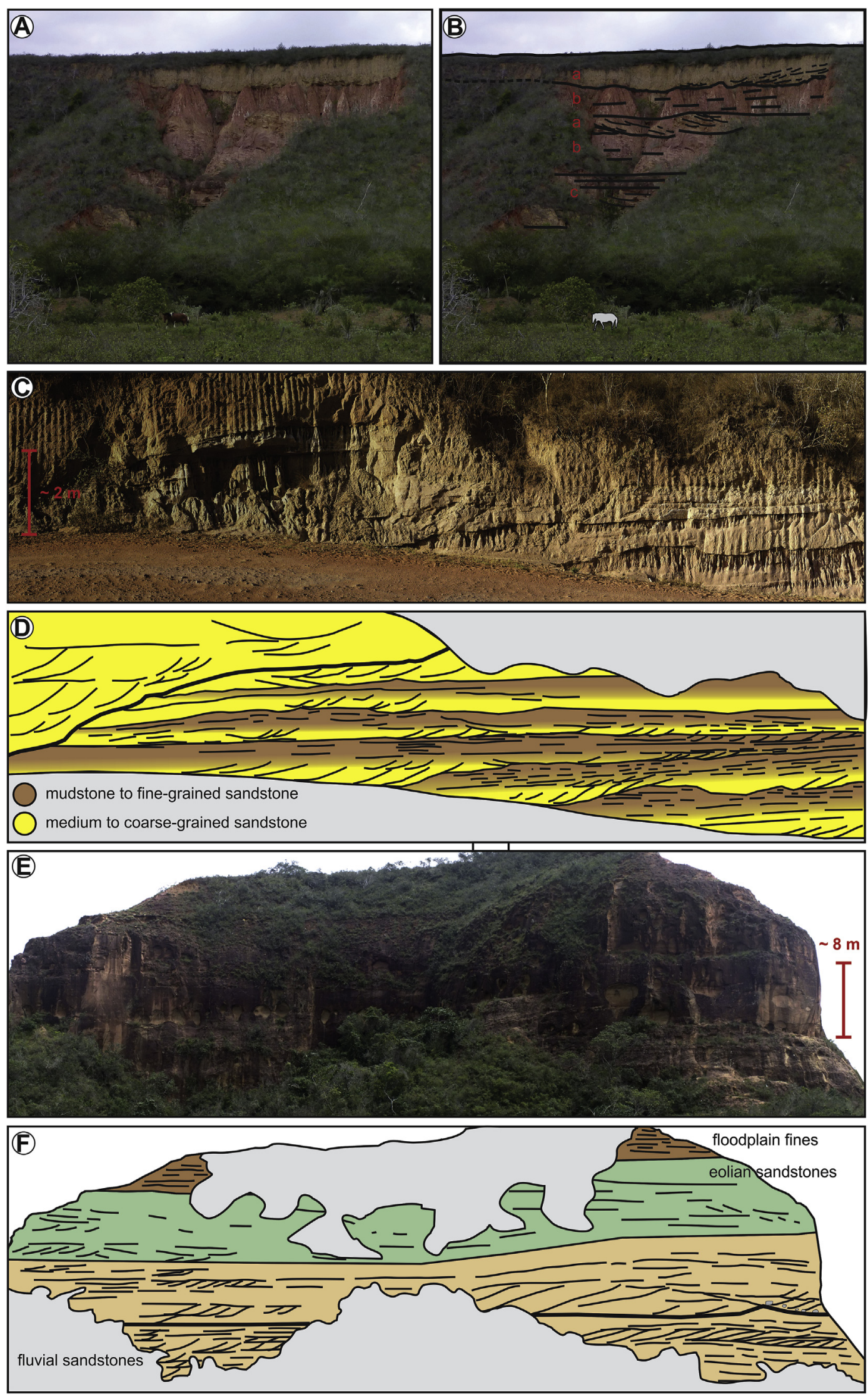

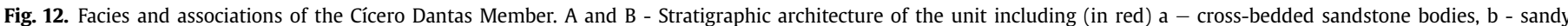

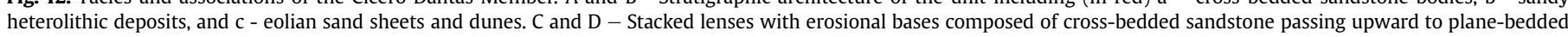

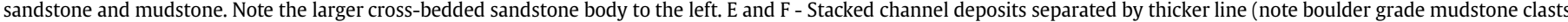

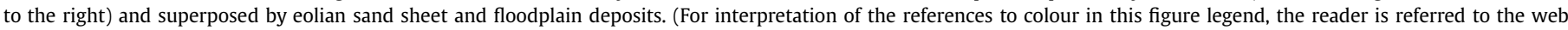
version of this article.) 

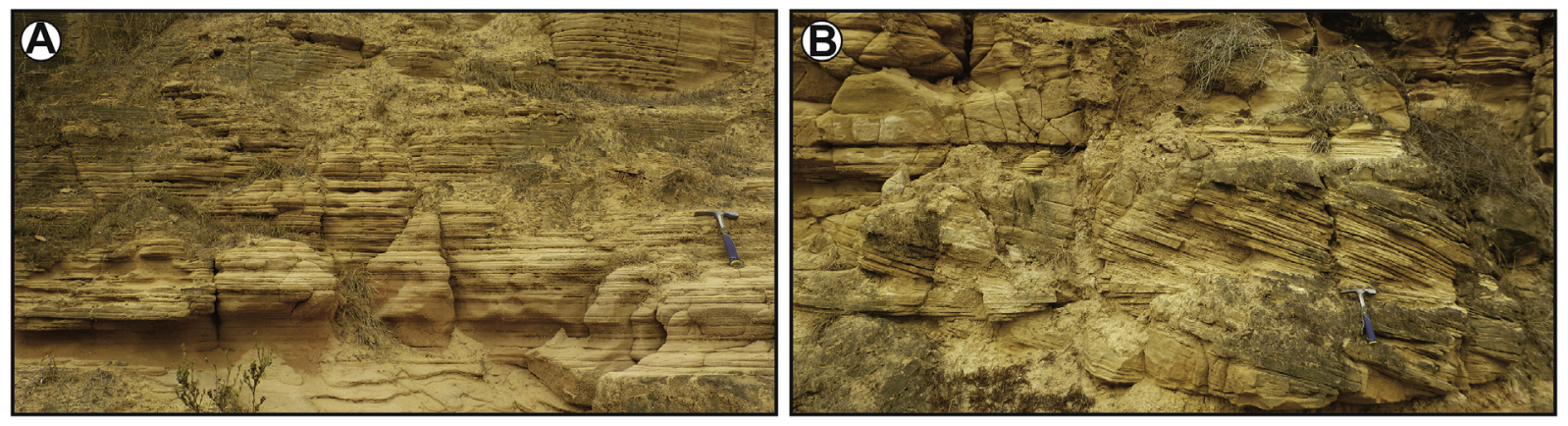

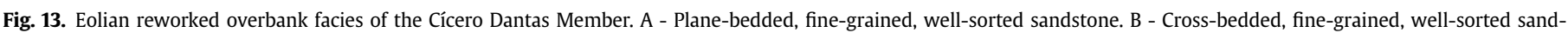
stone. Note pin stripe laminations in both facies.

to plane-bedded and low-angle cross-bedded sandstone (Fig. 12C and $\mathrm{D})$. The frequency of the latter facies association seems to increase in the proximities of large-scale cross-bedded sandstone bodies. Paleocurrents measured in these sandy heterolithic tabular deposits are usually characterized by high dispersion.

Large-scale cross-bedded sandstone bodies are several meterthick, medium to coarse-grained units, laterally continuous for hundreds to thousands of meters, with nearly flat bases and locally exposed steep truncations against heterolithic tabular successions (Fig. 12E and F). They are internally organized as meter-scale thick compound cross-stratified deposits (cosets), stacked to form packages separated by small-scale, cross-laminated, fine to medium-grained sandstone underlying erosional surfaces commonly marked by gravel-grade mudstone clasts. In the Central Tucano, this facies association can occur as well-exposed cliffforming deposits whereas in the South Tucano it usually occurs as deeply weathered conglomeratic sandstone bodies obliterated by abundant iron concretions and veins.

The relatively thin tabular cross-bedded sandstone bodies are meter-scale thick successions (Fig. 12A and B), laterally continuous for at least tens to hundreds of meters (scale of available outcrops). These deposits occur isolated within the heterolithic tabular facies association and are constituted of medium to coarse-grained crossbedded sandstone with rare granules and small pebbles concentrated in troughs. Both the above described cross-bedded sandstone bodies present minor thin conglomerate beds and paleocurrents towards the south, but with marked dispersion.

Meter-scale thick inclined heterolithic strata (IHS, sensu Thomas et al., 1987) were locally observed in the South Tucano. Muddominated IHS are often associated with small-scale cross-laminated fine to medium-grained sandstone, whereas medium to large-scale cross-stratified medium to coarse-grained sandstone are usually related to sandier IHS deposits.

The Cícero Dantas Member in the North Tucano occurs as a nearly $100 \mathrm{~m}$ thick succession in the Tonã Plateau bounded by carbonate-bearing deposits at the base and top (e.g. Almeida Filho et al., 2002; Varejão et al., 2016), respectively ascribed to the Amargosa Bed and to the Crato Formation (Figs. 1 and 2 A- $\mathrm{A}^{\prime}$ ). The unit is dominated by fine to medium-grained, micaceous, crossbedded sandstone, with subordinated occurrences of planebedded and small-scale cross-laminated sandstone, as well as coarse sand and granule rich beds. Measured paleocurrents provided mean paleoflow vectors towards SE-SSE (Fig. 14).

\subsubsection{Interpretation}

The Cícero Dantas Member is a fluvial sequence characterized by unconnected sandstone channel bodies. These channel bodies occur isolated within two types of tabular successions: a sandier one and a muddier one. The sandier tabular succession is interpreted as an overbank environment dominated by eolian reworking, whereas the muddier is interpreted as a floodplain overbank environment. In the former case, the facies association dominated by southward-flowing, small-scale cross-laminated sandstone and plane-bedded sandstone with parting lineation is interpreted to have been deposited during major floods, probably reworking eolian deposits, whereas plane-bedded sandstones without parting lineation associated with medium to large-scale cross-beds are interpreted as eolian sand sheets and dunes (Fig. 14).

The above interpreted overbank environments are possibly laterally equivalent, as they can be observed in vertical transitions. In this case the muddier floodplain deposits would be more proximal to river channels than the sandier overbank environment. On the other hand, eolian deposits were locally observed overlying channel-belt successions, what suggests channel-belt abandonment due to avulsion.

Less well-sorted cross-bedded sandstone intercalated in the muddier floodplain succession are interpreted as crevasse splay deposits. Their common occurrence near channel bodies and the association of trough cross-beds underlying plane-beds corroborate the interpretation of a high slope sub-environment, such as crevasse splays, in which the development of high Froude number flows are favored.

The cross-bedded sandstone bodies are interpreted as fluvial channel bodies. The larger ones are interpreted as amalgamated channel belt successions (Fig. 14) using the same criteria described in the interpretation of the Banzaê Member deposits - compound cross-strata, interpreted as unit bars and thalweg compound dunes, stacked to form multistory bodies bounded by bar top deposits and channel-belt basal erosional surfaces. The relatively thin tabular cross-bedded sandstone bodies are interpreted as the depositional products of minor channels in the floodplain, as well as the meterscale thick inclined heterolithic strata, interpreted as small point bars from such channels (e.g. Thomas et al., 1987).

The Cícero Dantas Member succession preserved in the Tonã Plateau, in the North Tucano, can be interpreted as the product of stacked channel belts of a basin-transverse river system, given its southeastward mean paleoflow vector, and its larger sandstone body connectivity compared to the Cícero Dantas Member elsewhere. Alternatively, it could be interpreted as an upstream reach of the main river system steered towards SE behind the Caritá Fault footwall. The coarser grain size of channel belt deposits southward, in the Central Tucano, compared to the Tonã Plateau deposits, could thus be a consequence of increased slope gradient associated with the continued rejuvenation of local source areas due to the activity of the Caritá Fault during the deposition of the Cícero Dantas Member. 


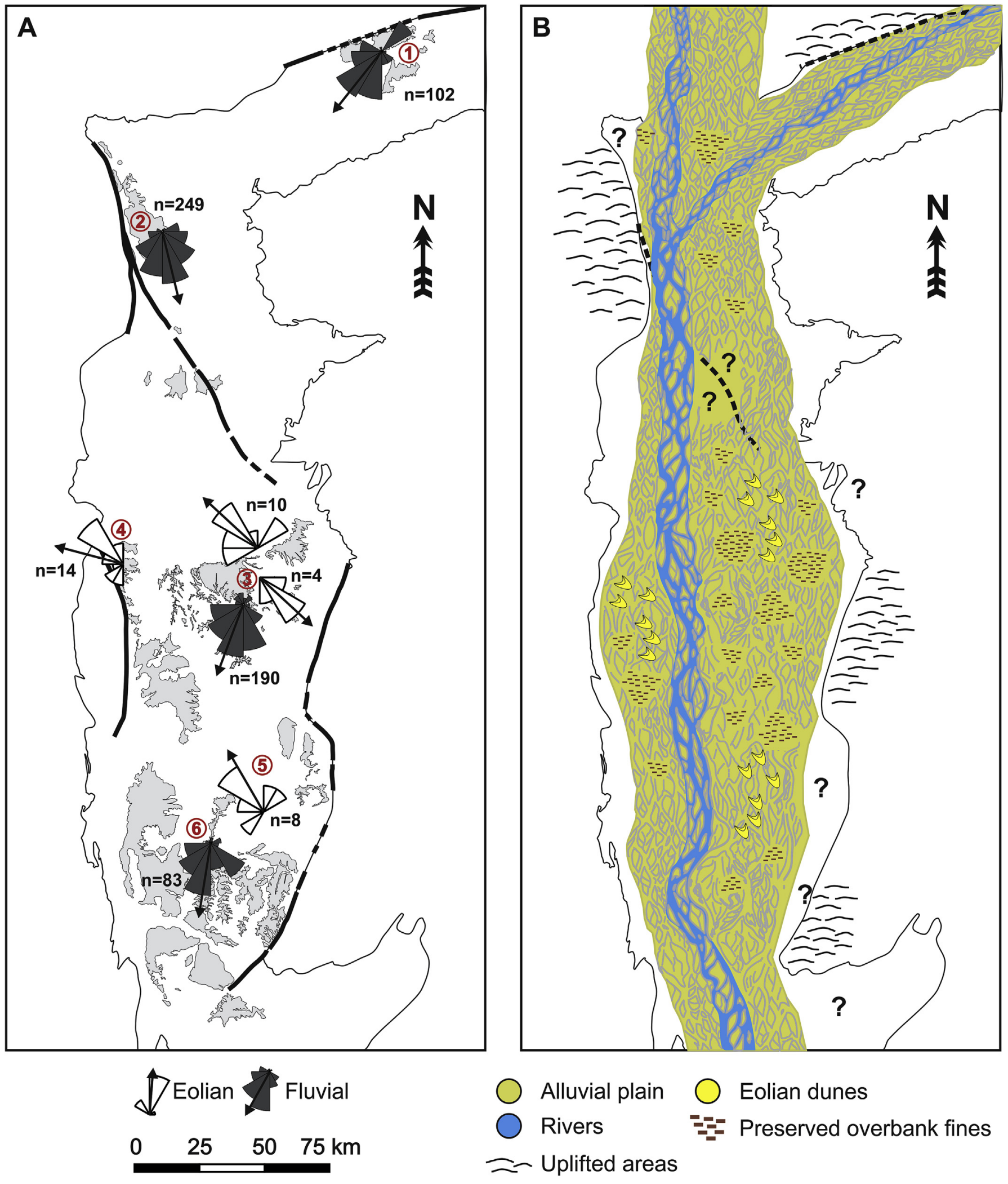

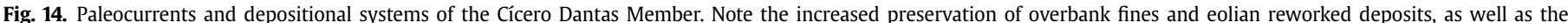

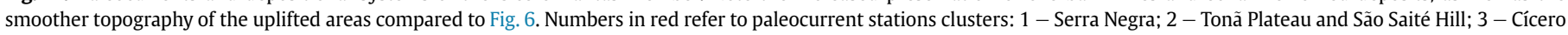

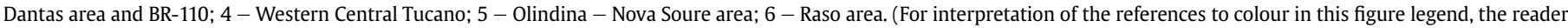
is referred to the web version of this article.) 


\section{Correlation of regional surfaces and paleogeographic implications}

The Aptian succession in the RTJ is bounded at the base by a regional erosional unconformity referred to as the pre-Aptian unconformity and used for regional correlation of the basins related to the South Atlantic opening during the Cretaceous. The pre-Aptian unconformity is recognized in interior basins of NE-Brazil, in basins of the Central segment of the South Atlantic in Brazil and Africa, as well as in basins of the Brazilian Equatorial margin (e.g. Bueno, 2004; Milani et al., 2007; Chaboureau et al., 2013).

In the RTJ rift system, this regional, erosional and locally angular unconformity is covered by fluvial and alluvial fan deposits of the Banzaê Member, often with the development of a basal conglomerate. Despite the presence of the latter deposits, no clear trend in grain size could be recognized in the Banzaê succession. Differences in grain-size are rather recognized between coeval sedimentary successions ascribed respectively to tributary and trunk fluvial systems.

The Amargosa Bed, preserved at the top of the Banzaê Member, display a basal contact characterized by a regional flat surface interpreted as a transgressive surface. Varejão et al. (2016) correlated this surface and the Amargosa succession with the Batateiras Bed in the Araripe Basin, recognizing its potential for broader correlations. Local occurrences of rippled finer grained deposits at the top of the Banzaê succession in the South Tucano are interpreted as a retrogradational sedimentary response to the base level variation associated with the deposition of the Amargosa Bed. The Amargosa Bed is regionally truncated by an erosional unconformity covered by the Cícero Dantas fluvial successions. The correlation of this surface with an erosional disconformity within the Barbalha Formation in the Araripe Basin (e.g. Chagas et al., 2007; Scherer et al., 2015; Fambrini et al., 2015) was also interpreted by Varejão et al. (2016).

No regional vertical trend was recognized in the Cícero Dantas Member in Central and South Tucano. However, stratigraphic profiles described by Varejão et al. (2016) in the Serra do Tonã area show a fining-upward trend interpreted by the authors as ascribed to a trangressive sedimentary response that culminated in the deposition of the carbonate-dominated Crato Formation succession.

On the other hand, in the northeast of the Tonã Plateau, fluvial deposits of the Cícero Dantas Member are truncated by a topographically expressed sharp flat surface underlying a heterolithic succession locally displaying mudcracks and ichnofossils (mostly U-shaped tube ascribed to Arenicolites icnogenus). This meterscale thick succession also present subordinate thin intercalations of marlstone, which pass upward to the limestone-dominated succession mapped as the Crato Formation. This situation suggests a second transgressive surface separating the Cícero Dantas fluvial deposits and the Crato Formation lacustrine (see Varejão et al., 2016) succession. The correlation of the following units of the Santana Group, preserved in small areas of the Jatobá Basin, lacks a detailed stratigraphic framework.

As a conclusion, the Aptian succession in the RTJ rift system, comprising the Marizal Formation and the Santana Group, can be described in terms of two fluvial-dominated depositional sequences (e.g. Varejão et al., 2016) that can be correlated with those of the Barbalha Formation in the Araripe Basin (e.g. Chagas et al., 2007; Assine, 2007; Fambrini et al., 2015; Scherer et al., 2015). Both sequences preserved in the RTJ and Araripe basins were affected by transgressive events recorded in contrasting shale and carbonate dominated successions close to their tops and separated of the fluvial succession by sharp flat transgressive surfaces.

The sedimentary record of a major southward continental paleodrainage, connecting at least the Araripe and the RTJ during the Aptian, and occasionally affected by transgression is thus crucial for understanding the timing and direction of marine ingressions into interior basins of Northeastern Brazil during the Aptian (e.g. Arai, 2014; Varejão et al., 2016; Assine et al., 2016).

\section{Autogenic vs. allogenic controls}

Fluvial stratigraphic architecture, often thought in terms of channel-belt clustering and sandstone body connectivity, is controlled by complex interactions between eustatic, tectonic and climatic, as well as autogenic processes, such as channel shift and avulsion (e.g. Allen, 1978; Leeder, 1978; Bridge and Leeder, 1979; Heller and Paola, 1996; Hajek et al., 2010; Hajek and Heller, 2012). A common approach in the endeavor to understand this inherently complex system is conceiving it as the result of the interplay between sedimentary input and generation of accommodation space (e.g. Kim et al., 2011; Hajek \& Wolinsky, 2012), both somehow controlled by the above mentioned variables.

The stacking of dunes and unit bars forming compound bars and then sequences capped by preserved bar-top and floodplain deposits as described in both members of the Marizal Formation is likely to be controlled by lateral channel shifting and ultimately by avulsion, thus configuring the autogenic-controlled channel-belt deposits (e.g. Puigdefábregas and Van Vilet, 1978; Godin, 1991; Robinson and McCabe, 1997; Bristow, 1996; McLaurin and Steel, 2007). Clustering of channel-belts, on its turn, can be the product of allogenic controls. Continental sequence stratigraphic models usually regard this amalgamated channel-belt deposits to low rates of sea level rise and fall affecting subsiding basins (e.g. Wright and Marriot, 1993; Shanley and McCabe, 1994).

Fluctuations in aggradation rates could also be controlled by tectonics, due to varied subsidence rates in space and time in tectonically active basins (e.g. Bridge and Leeder, 1979; Leeder and Gawthorpe, 1987; Bridge and Mackey, 1993; Mackey and Bridge, 1995; Gawthorpe and Leeder, 2000). A common sedimentary response ascribed to fluvial systems subject to varying subsidence and consequent tilting of the floodplain is the lateral migration of the channel belt towards areas with higher subsidence rates (e.g. Bridge and Leeder, 1979; Bridge and Mackey, 1993; Nanson, 1980a,b; Alexander and Leeder, 1987, 1990; Leeder and Alexander, 1987; Reid, 1992; Alexander et al., 1994; Peakall et al., 2000). This effect was obtained in numeric models in which avulsion is driven towards the topographic minimum, resulting in higher sandstone body connectivity within depocenters (e.g. Bridge and Leeder, 1979; Bridge and Mackey, 1993).

Further models considered avulsion frequency as a function of sedimentation rate (Mackey and Bridge, 1995; Heller and Paola, 1996) acknowledging observations from natural avulsion events (e.g. Fisk, 1951; Schumm, 1968; Smith et al., 1989; McCarthy et al., 1992; Richards et al., 1993) and flume experiments (e.g. Bryant et al., 1995; Hickson et al., 2005). In the latter case, avulsion and channel migration were observed to shift away from depocenter areas, where streams adjusted to increased generation of accommodation space enhancing sedimentation rate when capable of it. This process often resulted in isolated channel-belt sand bodies (e.g. Mackey and Bridge, 1995; Bryant et al., 1995; Heller and Paola, 1996; Hickson et al., 2005).

Additionally, channel-belt connectivity can also be controlled by autogenic parameters such as channel dimensions (depth and width) and avulsion frequency (e.g. Leeder, 1978; Bridge and Leeder, 1979; Alexander and Leeder, 1987; Bridge and Mackey, 1993; Mackey and Bridge, 1995). The self- organization of fluvial systems and its relation with depositional architecture have been subject of increasing interest and modeling (e.g. Jerolmack and 
Paola, 2010; Kim and Paola., 2007, 2011; Hajek et al., 2010, 2012; Hajek and Heller, 2012; Hajek and Wolinsky, 2012), resulting in a different view of autogenic dynamics operating in longer timescales than previously recognized and emulating architectural patterns also produced with the change of allogenic basin boundary conditions. Moreover, the autogenic dynamics of sediment transport systems have been shown by numeric models to modulate allogenic signals, often bringing uncertainties to the recognition of external controls in the basin fill architectural record (e.g. Jerolmack and Paola, 2007, 2010).

In spite of these models showing fluvial systems inherently filtering the signals of high frequency external controls (e.g. Jerolmack and Paola, 2010), climate-induced architectural shifts in the fluvial record are commonly evoked, based on vertical changes in features such as paleosols types and fossil content, as well as the proportion of sedimentary structures ascribed to seasonal discharge variability (e.g. North and Taylor, 1996; Bridge, 2003; Fielding et al., 2009, 2011; Allen et al., 2013).

Large-scale climate changes would influence fluvial architecture through changes in discharge regimes and consequently on sediment supply (e.g. Bridge, 2003). However, the most striking influences of climate change are related to post-glacial coupled climate-sea-level changes in the Quaternary (e.g. Blum and Törnqvist, 2000), what makes climate a minor concern in the interpretation of Mid-Cretaceous fluvial architecture, given the greenhouse conditions during the Cretaceous (e.g. Skelton et al., 2003).

The Marizal Formation presents contrasting fluvial stratigraphical architectures recorded in the basal Banzaê Member sandstone sheet and the isolated-channel style of the younger Cícero Dantas Member, separated from each other by a sequence boundary. A similar architectural contrast observed between the Cretaceous Lower and Middle Castlegate Sandstone, central USA, illustrated early models of non-marine sequence stratigraphy (e.g. Wright and Marriot, 1993; Shanley and McCabe, 1994). However, the complexity inherent to the theme has led to continuous revisions of earlier interpretations of the Castlegate Sandstone and the adjacent units (e.g. Adams and Bhattacharya, 2005; McLaurin and Steel, 2007; Hajek and Heller, 2012; Hampson et al., 2013).

Despite that, the sheet sandstone of the Banzaê Member could be interpreted in a continental sequence stratigraphy framework as controlled by low aggradation conditioned by low rates of base level rise or fall and/or low subsidence rates, notwithstanding the context of extensional tectonics and mechanic subsidence evidenced by alluvial fan deposits bounding major faults laterally related to the fluvial deposits. Together with the alluvial fan deposits, scarcely preserved floodplain fines constitute the subtle heterogeneities of the Banzaê Member and also occur restricted to the proximities of major faults, supporting the interpretation of fault-displacement-related subsidence associated with slightly higher sedimentation and, consequently, avulsion rates (e.g. Bryant et al., 1995; Heller and Paola, 1996; Hickson et al., 2005).

Considering the evidence of tectonically induced creation of accommodation during the deposition of the fluvial Banzaê Member, the transgression represented by the Amargosa Bed recorded at the top of the Banzaê Member could be related to rapid increase in tectonic space generation. However, the Amargosa Bed lies on top of proximal alluvial fan deposits in the eastern Central Tucano, suggesting the absence of border fault activation during its deposition. Thus, the Amargosa Bed and the underlying retrogradational succession probably would represent an adjustment to base level rise unrelated to increased tectonic activity.

The return of fluvial environments after the Amargosa transgression characterizes the reestablishment of a sediment overfilled basin. The evidence of reduced tectonic activity during the deposition of the Cícero Dantas Member, including the cessation of alluvial-fan deposition close to basin-borders, fewer brittle deformation, and deposition over faults affecting the Banzaê Member, is in apparent contradiction with the higher accommodation to sediment supply ratio interpreted from the isolated channels and increased preservation of floodplain deposits characteristic of the unit.

The most probable hypothesis to explain this involves a great reduction in the sedimentary input, balancing the reduced accommodation, as a consequence of the progressive denudation of sources and diminishing sedimentary yield after the last episodes of regional tectonic uplift during the Aptian. In this way, the Cícero Dantas Member could be considered as the record of the post-rift stage of evolution of the Cretaceous continental basins of Northeastern Brazil, either related to regional thermal subsidence (e.g. Magnavita et al., 1994; Japsen et al., 2012) or to the passive infill of the previous topography (e.g. Prosser, 1993) (e.g. Netto and Oliveira, 1985; Magnavita and Cupertino, 1987, 1988; Milani and Davison, 1988; Menezes Filho et al., 1988).

\section{Conclusions}

A new detailed view of the Aptian Marizal Formation (northeastern Brazil) is presented, with implications for the Cretaceous evolution of the extensional province of southwestern Gondwana to the Central South Atlantic. The Marizal Formation is here subdivided in two members, the lower Banzaê and the upper Cícero Dantas, displaying contrasting fluvial architectural styles and being separated by a sequence boundary over the transgressive record of the Amargosa Bed, a subaqueous fossiliferous marker bed preserved at the top of the Banzaê Member.

The new proposed sedimentary units are displayed in a geological sketch map emphasizing the distribution of the Aptian units, their deformational and syn-sedimentary large-scale structural features, and revealing a greater exposed area of the São Sebastião Formation than previously considered.

The broad dataset gathered here on the sedimentologic and stratigraphic aspects of the Aptian interval in the RecôncavoTucano-Jatobá rift system fosters the debate on the sedimentation controls and geodynamic significance of these successions. In this way, the interpretation of the onset of a thermal subsidence phase at the base of the Marizal Formation is disfavored by our results.

Generation of accommodation space during the onset of the Marizal Formation deposition was strongly controlled by mechanical subsidence, implying recurrent rift activity during the Aptian in the RTJ. Nonetheless, after the maximum flooding interval of the Marizal Formation recorded in the Amargosa Bed, accommodation space filled by the Cícero Dantas Member could be ascribed to previously interpreted mechanisms, such as thermal subsidence or subsidence cessation with the passive infill of the remnant topography.

The paleogeographic record of the Marizal Formation is dominated by a regional scale fluvial system axial to the Tucano Basin, and which displayed some major structurally controlled tributary systems along the sedimentary basin length. This large-scale river is part of a continental paleodrainage system, subject to occasional transgressions, connecting at least the Araripe and the RTJ basins.

The results here obtained thus point out to the need for a reappraisal of the meaning of the pre-Aptian unconformity, bringing new elements to the ongoing debate on the correlation of Cretaceous basins in northeastern Brazil and Africa and consequently to the paleogeographic and tectonic models for the evolution of the Cretaceous extensional province in western Gondwana. 


\section{Acknowledgements}

The authors are thankful to the São Paulo Research Foundation (FAPESP) which sponsored this work trough the research grants 2009/53363-8, 2013/01825-3, 2014/16739-8, 2016/03091-5, 2016/ 19736-5 and scholarship 2010/51559-0. Thanks are also due to CAPES (PROEX-558/2011) for student scholarships, to CNPq for researcher scholarships (301775/2012-5), and to Petrobras for research grants (2014/00519-9). The authors are very grateful to the welcoming and helpful people who live in the research area; to the students and colleagues who contributed during field work, specially Cristiano Galeazzi, Paulo Hino and André Stern; to the geologist Carolina Reis from the Geological Survey of Brazil for sharing her knowledge on the Tucano Basin geology; to the Chico Mendes Institute for Biodiversity Conservation (ICMBio) at Paulo Afonso-BA, to the National Indian Foundation (FUNAI) at Paulo Afonso-BA, and to Otávio Nolasco de Farias on behalf of the Serra Branca Private Environmental Protection Area at Jeremoabo-BA for logistical support and for granting us access to their land properties in the Tucano Basin. We are thankful to James Kellog, Claiton Scherer and Gelson Fambrini for their constructive reviews and editorial comments. This study is a NAP GEO-SEDEX contribution, with the institutional support of the University of São Paulo (PrPesq).

\section{References}

Adams, M.M., Bhattacharya, J.P., 2005. No change in fluvial style across a sequence boundary, Cretaceous Blackhawk and Castlegate Formations of central Utah, U.S.A. J. Sediment. Res. 75, 1038-1051.

Alexander, J. Leeder, M., 1987. Active tectonic control on alluvial architecture. In: Ethridge, F.G., Flores, R.M., Harvey, M.D. (Eds.), Recent Developments in Fluvia Sedimentology, vol. 39. SEPM Special Publication, pp. 243-252.

Alexander, J., Leeder, M.R., 1990. Geomorphology and surface tilting in an active extensional basin, SW Montana, USA. J. Geol. Soc. Lond. 147, 461-467.

Alexander, J., Bridge, J.S., Leeder, M.R., Collier, R.E.L., Gawthorpe, R.L., 1994. Holocene meander belt evolution in an active extensional basin, southwestern Montana. J. Sediment. Res. B64, 542-559.

Allen, J.P., Fielding, C.R., Rygel, M.C., Gibling, M.R., 2013. Deconvolving signals of tectonic and climatic controls from continental basins: an example from the Late Paleozoic Cumberland Basin, Atlantic Canada. J. Sediment. Res. 83 (10), $847-872$.

Allen, J.R.L., 1978. Studies in fluviatile sedimentation: an exploratory quantitative model for the architecture of avulsion-controlled alluvial suites. Sediment. Geol. 21, 129-147.

Allen, J.R.L., 1982. Sedimentary Structures: Their Character and Physical Basis Elsevier, Amsterdam, 594 pp.

Almeida, R.P., Freitas, B.T., Turra, B.B., Figueiredo, F.T., Marconato, A., Janikian, L. 2016a. Reconstructing fluvial bar surfaces from compound cross-strata and the interpretation of bar accretion direction in large river deposits. Sedimentology 63 (3), 609-628.

Almeida, R.P. Galeazzi, C.P., Freitas, B.T, Janikian, L, Ianniruberto, M., Marconato, A 2016b. Large barchanoid dunes in the Amazon River and the rock record: implications for interpreting large river systems. Earth Planet. Sci. Lett. 454 92-102.

Almeida Filho, R., Miranda, F.P., Yamakawa, T., Bueno, G.V., Moreira, F.R. Camargo, E.G., Bentz, C.M., 2002. Data integration for a geologic model of hydrocarbon microseepage areas in the Tonã Plateau region, North Tucano basin. Braz. Can. J. Remote Sens. 28 (1), 96-107.

Alvarado-Ortega, J., Brito, P.M., 2010. A new ichthyodectiform (actinopterygii, teleostei) from the lower cretaceous Marizal Formation, northeast Brazil. Palaeontology 53, 297-306.

Amaral, C.R.L., Brito, P.M., 2012. A new chanidae (ostariophysii: gonorynchiformes) from the cretaceous of Brazil with affinities to laurasian gonorynchiforms from Spain. PLoS ONE 7 (5), e37247. https://doi.org/10.1371/journal.pone.0037247.

Aragão, M.A., Peraro, A.A., 1994. Elementos estruturais do rifte tucano/jatobá. 3 simpósio do cretáceo do Brasil, rio claro. UNESP 161-164.

Arai, M., 2014. Aptian/albian (early cretaceous) paleogeography of the south atlantic: a paleontological perspective. Braz. J. Geol. 44, 339-350.

Aslanian, D., Moulin, M., Olivet, J.L., Unternehr, P., Matias, L., Bache, F., Rabineau, M., Nouzé, H., Klingelheofer, F., Contrucci, I., Labails, C., 2009. Brazilian and african passive margins of the central segment of the south atlantic ocean: kinematic constraints. Tectonophysics 468, 98-112.

Assine, M.L., 1994. Paleocorrentes e paleogeografia na Bacia do Araripe, Nordeste do Brasil. Rev. Bras. Geociências 24, 223-232.

Assine, M.L., 2007. Bacia do Araripe. Bol. Geociências Petrobras 15, 371-389.
Assine, M.L., Perinotto, J.A.J., Custódio, M.A., Neumann, V.H., Varejão, F.G., Mescolotti, P.C., 2014. Sequências deposicionais do Andar Alagoas da Bacia do Araripe, Nordeste do Brasil. Bol. Geociências Petrobras 22, 3-28.

Assine, M.L., Quaglio, F., Warren, L.V., Simões, M.G., 2016. Comments on paper by m. Arai "Aptian/Albian (early cretaceous) paleogeography of the south atlantic: a paleontological perspective". Braz. J. Geol. 46 (1), 3-7.

Blair, T.C., McPherson, J.G., 1994. Alluvial fans and their natural distinction from rivers based on morphology, hydraulic processes, sedimentary processes, and facies assemblages. J. Sediment. Res. 64, 450-489.

Blair, T.C., 1999. Sedimentary processes and facies of the waterlaid anvil spring canyon alluvial fan, death valley, California. Sedimentology 46, 913-940.

Blum, M.D., Törnqvist, T.E., 2000. Fluvial responses to climate and sea-level change: a review and look forward. Sedimentology 47, 2-48.

BRASIL, 1948. Relatório de 1947, Estado da Bahia. Conselho Nacional do Petróleo, Rio de Janeiro, pp. 91-182.

Brazil, J.J., 1947. Resume of geologic reconnaissance of the north half of the Bahia sedimentary, embayment northeast Bahia and west edge of Sergipe. S.I.. PETROBRÁS (Rei. Int. 20).

Braun, O.P.G., 1966. Estratigrafia dos sedimentos da parte inferior da região Nordeste do Brasil. Bol. Div. Geol. Mineral. Rio J. 236, 1-76.

Bridge, J.S., Leeder, M.R., 1979. A simulation model of alluvial stratigraphy. Sedimentology 26, 617-644.

Bridge, J.S., Mackey, S.D., 1993. A revised alluvial stratigraphy model. In: Marzo, M. Puigdefábregas, C. (Eds.), Alluvial Sedimentation, vol. 17. IAS Special Publication, pp. 319-336.

Bridge, J.S., 1993. Description and interpretation of fluvial deposits: a critical perspective. Sedimentology 40, 801-810.

Bridge, J.S., 2003. Rivers and Floodplains: Forms, Processes, and Sedimentary Record. Blackwell, $491 \mathrm{pp}$.

Bristow, C., 1996. Reconstructing fluvial channel morphology from sedimentary sequences. In: Carling, P.A., Dawson, M.R. (Eds.), Advances in Fluvial Dynamics and Stratigraphy. John Wiley \& Sons, Ltd, pp. 351-371.

Brito, P.M., Alvarado-Ortega, J., 2008. A new species of placidichthys (halecomorphi: ionoscopiformes) from the lower cretaceous Marizal Formation, northeastern Brazil, with a review of the biogeographical distribution of the ophiopsidae. In: Cavin, L., Longbottom, A., Richter, M. (Eds.), Fishes and the Break-up of Pangea, vol. 295. Geological Society of London Special Publication, pp. 145-154.

Bryant, M., Falk, P., Paola, C., 1995. Experimental study of avulsion frequency and rate of deposition. Geology 23, 365-368.

Bueno, G.V., 1996. Serra do Tonã: um elo estratigráfico entre as bacias de Tucano Norte (BA) e Araripe (CE). In: Nordeste do Brasil. 4 Simpósio Cretáceo do Brasil, Águas de São Pedro/Rio Claro. UNESP, pp. 135-142.

Bueno, G.V., 2004. Diacronismo de eventos no rifte Sul-Atlântico. Bol. Geosciências Petrobras 12, 203-229.

Caixeta, J.M., Bueno, G.V., Magnavita, L.V., Feijó, F.J., 1994. Bacias do Recôncavo, Tucano e Jatobá. Bol. Geociências Petrobras, Rio J. 8 (1), 163-172.

Castro Jr., A.C.M., 1987. The northeast Brazil and Gabon basins: a double rifting system associated with multiple detachment surfaces. Tectonics 6, 727-738.

Chaboureau, A.-C., Guillocheau, F., Robin, C., Rohais, S., Moulin, M., Aslanian, D., 2013. Paleogeographic evolution of the central segment of the South Atlantic during Early Cretaceous times: paleotopographic and geodynamic implications. Tectonophysics 604, 191-223.

Chagas, D.B., Assine, M.L., Freitas, F.I., 2007. Facies Sedimentares e ambientes deposicionais da Formação Barbalha no Vale do Cariri, Bacia do Araripe, Nordeste do Brasil. Geociências 26, 313-322.

Costa, I.P., Bueno, G.V., Milhomem, P.S., Silva, H.S.R.L., Kosin, M.D., 2007a. Sub-bacia de Tucano Norte e Bacia de Jatobá. Bol. Geociências Petrobras 15, 445-453.

Costa, I.P., Milhomem, P.S., Bueno, G.V., Silva, H.S.R.L., Kosin, M.D., 2007b. Sub-bacia de Tucano Sul e Central. Bol. Geociências Petrobras 15, 433-443.

Dantas, J.R.A., Filho, C.A.L., 2006. Síntese da geologia de Pernambuco. DNPM, $4^{\circ}$ Distrito - Pernambuco. http://www.dnpm-pe.gov.br/Sint_PE/Indice.php.

Destro, N., Szatmari, P., Alkmim, F.F., Magnavita, L.P., 2003. Release faults, associated structures, and their control on petroleum trends in the Recôncavo rift, northeast Brazil. AAPG Bull. 87, 1123-1144.

Fambrini, G.L., Menezes-Filho, J.A.B., Jesuíno, P.C.L., Araújo, J.T., Durval, L.G.L., Neumann, V.H.M.L., 2015. Sucessão faciológica da Formação Barbalha (Aptiano), Bacia do Araripe, Nordeste do Brasil. Estud. Geol. UFPE 25, 139-166.

Fielding, C.R., Allen, J.P., Alexander, J., Gibling, M.R., 2009. Facies model for fluvial systems in the seasonal tropics and subtropics. Geology 37, 623-626.

Fielding, C.R., Allen, J.P., Alexander, J., Gibling, M.R., Rygel, M.C., Calder, J.H., 2011. Fluvial systems and their deposits in the seasonal tropics and subtropics: modern and ancient examples. In: Davidson, S.K., Leleu, S., North, C.P. (Eds.), From River to Rock Record, vol. 97. SEPM Special Publication, pp. 89-112.

Figueiredo, F.J., 2004. A new euteleostean fish from the lower cretaceous. Arq. do Mus. Nac. do Rio J. 62, 293-307.

Figueiredo, F.T. Almeida, R.P., Freitas, B.T., Marconato, A., Carrera, S.C., Turra, B., 2016. Tectonic activation, source area stratigraphy and provenance changes in a rift basin: the Early Cretaceous Tucano Basin (NE-Brazil). Basin Res. 28, 433-445.

Fisk, H.N., 1951. Mississippi River Valley geology related to river regime. Am. Soc. Civ. Eng. Trans. 117, 667-682.

Gava, A., Nascimento, D.A., Vidal, J.L.B., Ghignone, J.I.P., Santiago Filho, A.L., Teixeira, W. Stanford, W.J.P., Ribeiro, A.G., Ribeiro, J.H.M., 1983. Geologia. In: Projeto RADAMBRASIL Folha SC.24/25 Aracaju/Recife. MME/SG, Rio de Janeiro, pp. 27-376 (Levantamento de Recursos Naturais, 30). 
Gawthorpe, R.L., Leeder, M.R., 2000. Tectono-sedimentary evolution of active extensional basins. Basin Res. 12, 195-218.

Godin, P., 1991. Fining-upward cycles in the sandy braided-river deposits of the westwater canyon member (upper jurassic), morrison formation, New Mexico. Sediment. Geol. 70, 61-82.

Hajek, E.A., Heller, P.L., 2012. Flow-depth scaling in alluvial architecture and nonmarine sequence stratigraphy: Example from the Castlegate Sandstone, central Utah, USA. J. Sediment. Res. 82, 121-130.

Hajek, E.A., Wolinsky, M.A., 2012. Simplified process modeling of river avulsion and alluvial architecture: connecting models and field data. Sediment. Geol. 257, $1-30$.

Hajek, E.A., Heller, P.L., Schur, E.L., 2012. Field test of autogenic control on alluvial stratigraphy (Ferris Formation, Upper Cretaceous-Paleogene, Wyoming). GSA Bull. 124, 1898-1912.

Hajek, E.A., Heller, P.L., Sheets, B.A., 2010. Significance of channel-belt clustering in alluvial basins. Geology 38, 535-538.

Hampson, G.J., Jewell, T.O., Irfan, N., Gani, M.R., Bracken, B., 2013. Modest change in fluvial style with varying accommodation in regressive alluvial-to-coastal-plain wedge: upper Cretaceous Blackhawk Formation, Wasatch Plateau, Central Utah, U.S.A. J. Sediment. Res. 83, 145-169.

Heller, P.L., Paola, C., 1996. Downstream changes in alluvial architecture: an exploration of controls on channel-stacking patterns. J. Sediment. Res. B66, 297-306.

Hickson, T.A., Sheets, B.A., Paola, C., Kelberer, M., 2005. Experimental test of tectonic controls on three-dimensional alluvial facies architecture. J. Sediment. Res. 75, 710-722.

Huismans, R.S., Beaumont, C., 2008. Complex rifted continental margins explained by dynamical models of depth-dependent lithospheric extension. Geology 36, 163.

Huismans, R.S., Beaumont, C., 2011. Depth-dependent extension, two-stage breakup and cratonic underplating at rifted margins. Nature 473, 74-78.

Japsen, P., Bonow, J.M., Green, P.F., Cobbold, P.R., Chiossi, D., Lilletveit, R., Pedreira, A., 2012. Episodic burial and exhumation in NE Brazil after opening of the South Atlantic. GSA Bull. 124, 800-816.

Jerolmack, D.J., Paola, C., 2007. Complexity in a cellular model of river avulsion. Geomorphology 91, 259-270.

Jerolmack, D.J., Paola, C., 2010. Shredding of environmental signals by sediment transport. Geophys. Res. Lett. 37, 19.

Karner, G.D., Driscoll, N.W., 1999. Tectonic and stratigraphic development of the West African and eastern Brazilian margins; insights quantitative basin Model In: Cameron, N.R., Clure, V.S. (Eds.), The Oil and Gas Habitats of the South Atlantic, vol. 153. Geological Society of London Special Publication, pp. 11-40.

Karner, G.D., Driscoll, N.W., Barker, D.H.N., 2003. Syn-rift region subsidence across the West African continental margin; the role of lower plate ductile extension. In: Arthur, T.J., MacGregor, D.S., Cameron, N.R. (Eds.), Geol. Soc. Lond. Special Publ. 207, 105-129.

Kim, W., Paola, C., 2007. Long-period cyclic sedimentation with constant tectonic forcing in an experimental relay ramp. Geology 35, 331-334.

Kim, W., Connel, S.D., Steel, E., Smith, G.A., Paola, C., 2011. Mass-balance control on the interaction of axial and transverse channel systems. Geology 39, 611-614.

Leeder, M., 1978. A quantitative stratigraphic model for alluvium, with special reference to channel deposit density and interconnectedness. In: Miall, A.D. (Ed.), Fluvial Sedimentology, Canadian Society of Petroleum Geologists Memoir, pp. 587-596.

Leeder, M.R., Alexander, J.A., 1987. The origin and tectonic significance of asymmetrical meander belts. Sedimentology 34, 217-226.

Leeder, M.R., Gawthorpe, R.L., 1987. Sedimentary models for extensional tilt-block/ half-graben basins. In: Coward, M.P., Dewey, J.F., Hancock, P.L. (Eds.), Continental Extensional Tectonics, vol. 28. Geological Society of London Special Publication, pp. 139-152.

Lima, C., Vilas Boas, G., 1994. Mecanismos de transporte e deposição dos Conglomerados da Formação Marizal (Cretáceo Inferior) na Bacia do Recôncavo, Bahia, Brasil. Braz. J. Geol. 24, 240-246.

Lima, C., Vilas Boas, G., 2000. A arquitetura deposicional da Formação Marizal (Cretáceo Inferior) na Bacia do recôncavo, Bahia. Braz. J. Geol. 30 (4), 729-736.

Lister, G.S., Etheridge, M.A., Symonds, P.A., 1986. Detachment faulting and the evolution of passive continental margins. Geology 14, 246-250.

Mackey, S.D., Bridge, J.S., 1995. Three dimensional model of alluvial stratigraphy: theory and application. J. Sediment. Res. B65, 7-31.

Magnavita, L.P., Cupertino, J.A., 1987. Concepção atual sobre as bacias do Tucano e Jatobá, Nordeste do Brasil. Bol. Geociências Petrobras 1, 119-134.

Magnavita, L.P., Cupertino, J.A., 1988. A new approach to the geological configuration of the lower cretaceous Tucano and Jatobá basins, northeastern Brazil. Rev. Bras. Geociências 18, 222-230.

Magnavita, L.P., 1992. Geometry and Kinematics of the Recôncavo-Tucano-Jatobá Rift. NE Brazil: Ph.D. thesis. University of Oxford, England.

Magnavita, L.P., Davison, I., Kusznir, N.J., 1994. Rifting, erosion, and uplift history of the Recôncavo-Tucano-Jatobá Rift, northeast Brazil. Tectonics 13, 367-388.

Magnavita, L.P., Destro, N., Carvalho, M.S.S., Milhomem, P.S., Souza-Lima, W., 2003. Bacia de Tucano. Aracaju, Fundação Paleontológica Phoenix. Séries Bacias Sedimentares, ano 5 , n 52.

Magnavita, L.P., Silva, R.S., Sanches, C.P., 2005. Roteiros geológicos, guia de campo da Bacia do Recôncavo, NE do Brasil. Bol. Geociências Petrobras 13, 301-334.

Magnavita, L., Vilas Boas, G.S., Lima, C.C.U., 2000. Evidence of tectonic activity during the deposition of the Marizal formation, the post-rift unit of the
Recôncavo Basin, Northeastern Brazil. In: 31st International Geological Congress., Rio de Janeiro, 6-17/August.

Marton, L.G., Tari, L.G., Lehmann, C.T., 2000. Evolution of the Angolan passive margin, West Africa, with emphasis on post-salt structural styles. In: Mohriak, W., Talwani, M. (Eds.), Atlantic Rifts and Continental Margins, American Geophysical Union, Geophysical Monograph Series, vol. 115, pp. 129-149.

Matos, R.M.D., 1992. The northeast Brazilian rift system. Tectonics 11, 766-791.

Matos, R.M.D., 1999. History of the Northeast Brazilian rift system; kinematic implications for the break-up between Brazil and West Africa. In: Cameron, N.R. Bate, R.H., Clure, V.S. (Eds.), The Oil and Gas Habitats of the South Atlantic, vol. 153. Geological Society of London Special Publication, pp. 55-73.

McCarthy, T.S., Ellery, W.N., Stanistreet, I.G., 1992. Avulsion mechanisms on the Okavango fan, Botswana: the control of a fluvial system by vegetation. Sedimentology 39, 779-795.

McKenzie, D., 1978. Some remarks on the development of sedimentary basins. Earth Planet. Sci. Lett. 40, 25-32.

McLaurin, B.T., Steel, R.J., 2007. Architecture and origin of an amalgamated fluvial sheet sand, lower Castlegate Formation, Book Cliffs, Utah. Sediment. Geol. 197, 291-311.

Menezes Filho, N.R., Santos, R.A., Souza, J.D., 1988. Jeremoabo, folha SC.24-Z-A-II: Estado da Bahia. Escala 1:100.000. Brasília: DNPM, 1988. 154 p. Programa Levantamentos Geológicos Básicos do Brasil - PLGB. Convênio DNPM/CPRM.

Miall, A.D., 1985. Architectural-element analysis: a new method of facies analysis applied to fluvial deposits. Earth Sci. Rev. 22, 261-308.

Miall, A.D., 1996. The Geology of Fluvial Deposits. Springer, 582 pp.

Milani, E.J., Davison, I., 1988. Basement control and transfer tectonics in the Recôncavo-Tucano-Jatobá rift, Northeast Brazil. Tectonophysics 154, 41-70.

Milani, E.J., Rangel, H.D., Bueno, G.V., Stica, J.M., Winter, W.R., Caixeta, J.M., Pessoa Neto, O.C., 2007. Bacias Sedimentares Brasileiras - Cartas Estratigráficas, vol. 15 Boletim de Geociências da Petrobras, Rio de Janeiro.

Nanson, G.C., 1980a. Point bar and floodplain formation of the meandering Beatton River, northeastern British Columbia, Canada. Sedimentology 27, 3-29.

Nanson, G.C., 1980b. A regional trend to meander migration. J. Geol. 88, 100-108.

Netto, A.S.T., Oliveira, J.J., 1985. O preenchimento do "rift-valley" na Bacia do Recôncavo. Rev. Bras. Geol. 15, 97-102.

Neumann, V.H.M.L., Rocha, D.E.G.A., Moraes, A.S., Sial, A.N., Taboada Castro, M.T., Barbosa, J.A., Fambrini, G.L., Carvalho, R.R., 2010. Microfácies carbonáticas e comportamento isotópico de C e O nos calcários laminados aptianos lacustres da Serra Negra, Bacia do Jatobá, Nordeste do Brasil. Estud. Geol. 20, 89-100.

Neumann, V.H.M.L., Rocha, D.E.G.A., 2013. Stratigraphy of the post-rift sequences of the Jatobá Basin, northeastern Brazil. Strati 2013. Springer Geol. 553-557. https://doi.org/10.1007/978-3-319-04364-7_106.

Neumann, V.H.M.L., Rocha, D.E.G.A., Vortisch, W., Gratzer, R., Lima Filho, M. Barbosa, J.A., Fambrini, G.L., 2013. Sedimentary facies and palaeoenvironmental records of an intracratonic basin lake: aptian lacustrine Crato Formation, Jatobá Basin, NE Brazil. Search Discov. Article, AAPG 19-22.

North, C.P., Taylor, K.S., 1996. Ephemeral-fluvial deposits: integrated outcrop and simulation studies reveal complexity. AAPG Bull. 80, 811-830.

Peakall, J., Leeder, M., Best, J., Ashworth, P., 2000. River response to lateral ground tilting: a synthesis and some implications for the modelling of alluvial architecture in extensional basins. Basin Res. 12, 413-424.

Petri, S., 1987. Cretaceous paleogeographic maps of Brazil. Palaeogeography Palaeoclimatology. Palaeoecology 59, 117-168.

Prosser, S., 1993. Rift-related Linked Depositional Systems and Their Seismic Expression, 71. Geological Society of London Special Publication, pp. 35-66.

Puigdefábregas, C., Van Vilet, A., 1978. Meandering stream deposits from the Tertiary of the southern Pyrenees. In: Miall, A.D. (Ed.), Fluvial Sedimentology, vol. 5. Canadian Society of Petroleum Geologists Memoir, pp. 469-485.

Reading, H.G., 1986. Facies. In: Reading, H.G. (Ed.), Sedimentary Environments and Facies, second ed., pp. 4-19 Blackwell.

Reading, H.G., 1996. Sedimentary Environments: Processes. Facies and Stratigraphy, Blackwell, 688pp.

Reesink, A.J.H., Bridge, J.S., 2007. Influence of superimposed bedforms and flow unsteadiness on formation of cross strata in dunes and unit bars. Sediment. Geol. 202, 281-296.

Reesink, A.J.H., Bridge, J.S., 2009. Influence of superimposed bedforms and flow unsteadiness on formation of cross strata in dunes and unit bars - Part 2, further experiments. Sediment. Geol. 222, 274-300.

Reesink, A.J.H., Bridge, J.S., 2011. Evidence of bedform superimposition and flow unsteadiness in unit bar deposits, South Saskatchewan River, Canada. J. Sedimenatry Res. 81, 814-840.

Reid, J.B., 1992. The owens river as a tiltmeter for long valley caldera, California. J. Geol. 100, 353-363.

Reis, M.A.F., Dino, R., Pereira, E., Antonioli, L., 2007. Dados palinológicos da Formação Marizal da Bacia do Recôncavo, Nordeste do Brasil. In: Carvalho, I.S. Cassab, R.C.T., Schwanke, C., Carvalho, M.A., Fernandes, A.C.S., Rodrigues, M.A.C. Carvalho, M.S.S., Arai, M., Oliveira, MEQ (Orgs) (Eds.), Paleontologia: Cenários de Vida. 1ed, vol. 2007. Editora Interciência, Rio de Janeiro, pp. 559-573, 2.

Richards, K., Chandra, S., Friend, P., 1993. Avulsive channel systems: characteristics and examples. In: Best, J.L., Bristow, C.S. (Eds.), Braided Rivers, vol. 75 Geological Society of London Special Publication, pp. 195-203.

Robinson, J.W., McCabe, P.J., 1997. Sandstone-body and shale body dimensions in a braided f luvial system: salt wash sandstone member (morrison formation) garfield county, Utah. AAPG Bull. 81, 1267-1291.

Rocha, D.E.G.A., 2011. Caracterização do intervalo carbonático do sistema lacustre 
aptiano da Bacia do Jatobá, NE do Brasil. Tese de doutorado. Universidade Federal do Pernambuco, $128 \mathrm{pp}$.

Rolim, J.L., Mabesoone, J.M., 1982. Um modelo de grande rio para as bacias do Recôncavo-Tucano-Jatobá (Pubeckiano-Aptiano, Nordeste do Brasil). In: SBG, $32^{\circ}$ Congresso Brasileiro de Geologia, Salvador, 4, Anais, pp. 1406-1412.

Rolim, J.L., 1984. Estudo da Seqüência clástica e carbonática da Serra do Tonâ, Macururé, Estado da Bahia. Tese de doutorado em Geociências. UFRGS, Porto Alegre, $155 \mathrm{pp}$.

Sambrook Smith, G.H., Ashworth, PJ., Best, J.L., Woodward, J., Simpson, C.J., 2006. The sedimentology and alluvial architecture of the sandy braided South Saskatchewan River, Canada. Sedimentology 53, 413-434.

Santos, C.A., Neumann, V.H., Menezes, M.R.F., Rocha, D.E.G.A., Agostinho, S., 2011 Caracterização sedimentológica e micropaleontológica dos calcários bioclásticos da Serra do Periquito, Bacia do Jatobá - PE. Estudos Geológicos. UFPE 21, 21-39.

Santos, C.C. \& Reis, C., 2011. Projeto Bacia do Tucano Central: Folha Caimbé - SC.24 Z-A-I, Folha Jeremoabo - SC.24-Z-A-II: Estado da Bahia. Salvador: CPRM, 2011 99 p. il. Escala 1:100.000. Programa Geologia do Brasil. Levantamentos Geológicos Básicos.

Santos, C.C., Reis, C., Pedreira, A.J., 2010. Projeto Bacia do Tucano Central: Folha Ribeira do Pombal - SC.24-Z-A-IV; Folha Cícero Dantas - SC.24-Z-A-V. Estado da Bahia e Sergipe. Salvador: CPRM, 2010. 87 p. il. Escala 1:100.000. Programa Geologia do Brasil. Levantamentos Geológicos Básicos.

Scherer, C.M.S., Goldberg, K., Bardola, T., 2015. Facies architecture and sequence stratigraphy of an early post-rift fluvial succession, Aptian Barbalha Formation, Araripe Basin, northeastern Brazil. Sediment. Geol. 322, 43-62.

Schumm, S.A., 1968. Speculations concerning paleohydrologic control of terrestial sedimentation. GSA Bull. 79, 1573-1588.

Shanley, K.W., McCabe, P.J., 1994. Perspectives on the sequence stratigraphy of continental strata. AAPG Bull. 78, 544-568.

Silva Santos, R., 1972. Peixes da Formação Marizal, Estado da Bahia. Tese de doutorado. Universidade de São Paulo, Instituto de Geociências, São Paulo. vii + 76 pp., 11 estampas.

Silva, O.B., Caixeta, J.M., Milhomem, P.S., Kosin, M.D., 2007. Bacia do recôncavo. Bol. Geociências Petrobras 15, 423-431.

Silveira, A.C., Varejão, F.G., Neumann, V.H., Sial, A.N., Assine, M.L., Ferreira, V.P., Fambrini, G.L., 2014. Quimioestratigrafia de carbono e oxigênio dos carbonatos lacustres aptiano da Serra do Tonã, sub-bacia de Tucano Norte, NE do Brasil. Estud. Geol. 24 (2), 47-63.

Skelton, P.W., Gilmour, I., Kelley, S.P., Spicer, R.A., 2003. Cretaceous World. Cambridge University Press, 360 pp.
Smith, N.D., Cross, T.A., Dufficy, J.P., Clough, S.R., 1989. Anatomy of an avulsion. Sedimentology 36, 1-23.

Souza, J.D., et al., 2003. Mapa Geológico do Estado da Bahia. In: CPRM - SERVIÇO GEOLÓGICO DO BRASIL. Geologia e Recursos Minerais do Estado da Bahia: Sistema de Informações Geográficas - SIG. [Geology and Mineral Resources of the Bahia State: Geographic Information System - GIS]. Versão 1.1. Salvador: CPRM, 2003. 1 CD-ROM. Mapas na escala 1:1.000.000 e 1:2.000.000. Convênio CPRM/CBPM.

Tamura, L.N., Almeida, R.P., Taioli, F., Marconato, A., Janikian, L., 2016. Ground penetrating radar investigation of depositional architecture: the São Sebastião and Marizal formations in the Cretaceous Tucano Basin (Northeastern Brazil). Braz. J. Geol. 46 (1), 15-27.

Thomas, R., Smith, D., Wood, J., Visser, J., Calverley-Range, E., Koster, E., 1987. Inclined heterolithic stratification - terminology, description, interpretation and significance. Sediment. Geol. 53, 123-179.

Tomé, M.E., Lima Filho, M.F. 2010. Ostracodes da Bacia de Cedro, Andar Alagoas, Estado de Pernambuco, NE, Brasil: Implicaç̃es Paleoambientais e Bioestratigráficas. Estud. Geol. vol. 21 (2), 56-70.

Unternehr, P., Peron-Pinvidic, G., Manatschal, G., Sutra, E., 2010. Hyper-extended crust in the South Atlantic; in search of a model. Pet. Geosci. 16, 207-215.

Ussami, N., 1986. Crustal detachment during South Atlantic rifting and formation of Tucano-Gabon basin system. Nature 322, 629-632.

Varejão, F.G., Warren, L.V., Perinotto, J.A.J., Neumann, V.H., Freitas, B.T., Almeida, R.P. Assine, M.L., 2016. Upper Aptian mixed carbonate-siliciclastic sequences from Tucano Basin, Northeastern Brazil: implications for paleogeographic reconstructions following Gondwana break-up. Cretac. Res. 67, 44-58.

Vasconcellos, D.V.F. 2003. Falha de transferência de Caritá: O significado tectônico no rifte do Recôncavo-Tucano-Jatobá, NE Brasil. Dissertação de mestrado. Universidade Federal de Ouro Preto, Minas Gerais, 82 pp.

Viana, C.F., Junior, E.G.G., Simões, I.A., Moura, J.A., Fonseca, J.D.R., Alves, R.J., 1971. Revisão estratigráfica da Bacia Recôncavo/Tucano. Bol. Técnico Petrobras 14, 157-192.

Walker, R.G., 1992. Facies, facies models and modern stratigraphic concepts. In: Walker, R.G., James, N.P. (Eds.), Facies Models and Response to Sea-level Change. Geological Association of Canada, pp. 1-14. Geotext 1.

Wernicke, B.P., 1985. Uniform-sense normal simple shear of the continental lithosphere. Can. J. Earth Sci. 22, 108-125.

Wright, V.P., Marriot, S.B., 1993. The sequence stratigraphy of fluvial depositional systems: the role of floodplain sediment storage. Sediment. Geol. 86, 203-210. 